(c) American Dairy Science Association, 2005.

\title{
Invited Review: Prevalence of Shiga Toxin-Producing Escherichia coli in Dairy Cattle and Their Products
}

\author{
H. S. Hussein and T. Sakuma \\ Department of Animal Biotechnology, University of Nevada-Reno, Reno 89557
}

\begin{abstract}
The main objective of this review was to assess the role of dairy cattle and their products in human infections with Shiga toxin-producing Escherichia coli (STEC). A large number of STEC strains (e.g., members of the serogroups O26, O91, O103, O111, O118, O145, and O166) have caused major outbreaks and sporadic cases of human illnesses that have ranged from mild diarrhea to the life-threatening hemolytic uremic syndrome. These illnesses were traced to $\mathrm{O} 157$ and nonO157 STEC. In most cases, STEC infection was attributed to consumption of ground beef or dairy products that were contaminated with cattle feces. Thus, dairy cattle are considered reservoirs of STEC and can impose a significant health risk to humans. The global nature of food supply suggests that safety concerns with beef and dairy foods will continue and the challenges facing the dairy industry will increase at the production and processing levels. In this review, published reports on STEC in dairy cattle and their products were evaluated to achieve the following specific objectives: 1) to assemble a database on human infections with STEC from dairy cattle, 2) to assess prevalence of STEC in dairy cattle, and 3) to determine the health risks associated with STEC strains from dairy cattle. The latter objective is critically important, as many dairy STEC isolates are known to be of high virulence. Fecal testing of dairy cattle worldwide showed wide ranges of prevalence rates for $\mathrm{O} 157$ (0.2 to $48.8 \%)$ and non-O157 STEC (0.4 to $74.0 \%)$. Of the 193 STEC serotypes of dairy cattle origin, 24 have been isolated from patients with hemolytic uremic syndrome. Such risks emphasize the importance and the need to develop long-term strategies to assure safety of foods from dairy cattle.
\end{abstract}

(Key words: foodborne pathogen, Escherichia coli, dairy cattle, Shiga toxin)

Abbreviation key: $\boldsymbol{e a e}=E$. coli attaching and effacing gene, $\boldsymbol{e h} \boldsymbol{x} \boldsymbol{A}=$ enterohemolysin gene, HUS = hemolytic

Received March 31, 2004.

Accepted August 31, 2004.

Corresponding author: H. S. Hussein; e-mail: hhussein@cabnr. unr.edu. uremic syndrome, HUT = an untypeable $\mathrm{H}$ antigen, $\mathbf{H}^{-}=$nonmotile, $\mathbf{O R}=$ a rough $\mathrm{O}$ antigen, $\mathbf{O U T}=$ an untypeable $\mathrm{O}$ antigen, $\mathbf{O X 3}=$ the provisional designation for the O174 antigen, STEC = Shiga toxin-producing $E$. coli, $\mathbf{S t x} \mathbf{1}=$ Shiga toxin $1, \boldsymbol{s t} \boldsymbol{x}_{\mathbf{1}}=$ Shiga toxin 1 gene, $\mathbf{S t x} 2=$ Shiga toxin $2, \boldsymbol{s t x}_{2}=$ Shiga toxin 2 gene .

\section{INTRODUCTION}

The safety concern about foods of bovine origin emerged 2 decades ago and increased in recent years because of the growing number of human infections with Shiga toxin-producing Escherichia coli (STEC). These infections result in illnesses (Griffin and Tauxe, 1991) such as mild diarrhea, bloody diarrhea, hemorrhagic colitis, and hemolytic uremic syndrome (HUS). Hemolytic uremic syndrome can lead to acute or chronic renal failure, especially in children (Siegler et al., 1991). Other illnesses include strokes (Griffin and Tauxe, 1991) and thrombotic thrombocytopenic purpura that is characterized by nervous system abnormalities (Paton and Paton, 2000).

Dairy cattle are considered reservoirs of O157 (Besser and Hancock, 1994; Hancock et al., 1994; Mechie et al., 1997) and non-O157 STEC (Rahn et al., 1997; Conedera et al., 2001; Kobayashi et al., 2001). Contamination of raw milk (Wells et al., 1991; Sandhu et al., 1996; Chiueh et al., 2002), cheese (Clarke et al., 1994; Pradel et al., 2000; Pradel et al., 2001), or ground beef from dairy cattle (Doyle, 1991) poses a significant risk to humans. Raw milk caused a small number of human illness outbreaks (USDA-APHIS-VS, 1997) that were traced to O157 (Martin et al., 1986; Borczyk et al., 1987; Lahti et al., 2002) and non-O157 STEC (CDC, 1995; Bielaszewska et al., 2000; Allerberger et al., 2001). Outbreaks and sporadic cases of illnesses were also traced to consumption of STEC-contaminated cheese (Deschênes et al., 1996; CDC, 2000) and yogurt (Morgan et al., 1993). Culled dairy cows are mainly used for production of ground beef (USDA-APHIS-VS, 1996a) and therefore can impose a significant health risk (Ostroff et al., 1990; Doyle, 1991; Faith et al., 1996). Because of the increased concern with the safety of ground beef and dairy products in recent years, the objective of this review was 
to assess the role of dairy cattle in human infections with STEC.

\section{VIRULENCE FACTORS OF STEC}

In addition to $E$. coli $\mathrm{O} 157: \mathrm{H} 7,>100$ STEC serotypes (e.g., members of the O26, O91, O103, O111, O118, O145, and O166 serogroups) are known to cause human illnesses, including HUS (Paton and Paton, 2000). Pathogenic STEC strains are often referred to as enterohemorrhagic $E$. coli and are known to produce 1 or 2 toxins that resemble those of Shigella dysenteriae (O'Brien and Holmes, 1987). These are Shiga toxin 1 (Stx1) and Shiga toxin 2 (Stx2). The STEC strains can also produce other virulence factors such as those responsible for intimate attachment to the intestinal surface (intimin) and for enterocyte damage (enterohemolysin). In addition to $E$. coli $\mathrm{O} 157: \mathrm{H} 7$, members of the O26, O103, and O111 serogroups are considered the most important enterohemorrhagic $E$. coli (Franke et al., 1995). Although Stx1 and Stx2 are different proteins, encoded by the Shiga toxin 1 gene $\left(\boldsymbol{s t} \boldsymbol{x}_{1}\right)$ and the Shiga toxin 2 gene $\left(\boldsymbol{s t x}_{2}\right)$, respectively, their biological activities are quite similar (Neill, 1997). It is worth noting that STEC-related illnesses can be caused by an $E$. coli strain that produces Stx1, Stx2, or both toxins (Lior, 1994). Other virulence factors (intimin and enterohemolysin) are encoded by the $E$. coli attaching and effacing (eae) and enterohemolysin (ehxA) genes. The eae and ehxA genes are found in virtually all $E$. coli O157 strains (Neill, 1997) and appear to be more common in the non-O157 STEC strains responsible for human illnesses (Beutin et al., 1994). The eae and ehxA genes, however, are not absolutely required to cause human illnesses because STEC strains lacking these genes were shown to cause human illnesses (Neill, 1997). Therefore, each STEC strain should be considered a potential enterohemorrhagic $E$. coli (Bürk et al., 2002).

\section{HUMAN INFECTIONS WITH STEC FROM DAIRY CATTLE}

Most human STEC infections have been traced to consumption of contaminated foods of bovine origin such as ground beef (Griffin and Tauxe, 1991; USDAAPHIS-VS, 1997) and raw milk (Herriott et al., 1994; Lahti et al., 2002). Other infection routes include manure-contaminated vegetables (Cieslak et al., 1993), person to person (Reida et al., 1994), animal to person (Crump et al., 2002), and contaminated water through drinking (Yatsuyanagi et al., 2002) or swimming (Keene et al., 1994). Beef from dairy cattle, raw milk, and some of the dairy products are considered contributing fac- tors to STEC infections (Martin et al., 1986; Steele et al., 1997). Shiga toxin-producing $E$. coli also can spread from the dairy farm environment to humans by touching the animals (Crump et al., 2002). These pathogens were prevalent at high rates on US dairy farms (Zhao et al., 1995) and were widely distributed in the dairy farm environment (Zhao et al., 1995).

Several outbreaks and sporadic cases of human illnesses caused by infection with $E$. coli $\mathrm{O} 157$ (O157:H7, O157: $\mathbf{H}^{-}$[nonmotile], or other isolates that were not typed for the $\mathrm{H}$ antigen) from dairy cattle (Table 1) emphasized the role of raw milk as an important vehicle of transmission (Reitsma and Henning, 1996). With regard to $E$. coli O157:H7, 2 US outbreaks (Herriott et al., 1994; USDA-APHIS-VS, 1997) were caused by consumption of raw milk in 1992 (9 cases) and 1993 (6 cases) and were traced to 2 dairies that were licensed to sell raw milk (USDA-APHIS-VS, 1994). Drinking raw milk in the US resulted in HUS cases in Wisconsin (Martin et al., 1986), Washington State (Wells et al., 1991), and Oregon (Keene et al., 1997). Raw milk also caused human illnesses in Canada (Borczyk et al., 1987; Wilson et al., 1996) and Finland (Lahti et al., 2002). Fortunately, the number of raw milk drinkers in Western societies is small. It was estimated that 1 to $2 \%$ of the US population consume raw milk (USDA-APHISVS, 1994). Raw milk consumption, however, has decreased from 429 million $\mathrm{kg}$ in 1980 to 230 million $\mathrm{kg}$ in 1990 (USDA, 1992). These statistics may explain why the number of STEC outbreaks caused by raw milk consumption has been small.

Outbreaks caused by E. coli O157-contaminated dairy products are limited. For example, the only reported yogurt outbreak occurred in the UK in 1991 (Morgan et al., 1993) and involved 16 people, of which 5 had HUS. Only one cheese outbreak was reported in the US (Wisconsin) and involved 55 people. In addition to the 4 cheese outbreaks that occurred in the UK (Table 1), 2 cheese outbreaks were also reported in France (Anonymous, 1994) and the UK (Curnow, 1994). Other contaminated dairy products (butter and unpasteurized cream) were the cause of $\mathrm{O} 157$ infection in one (Reid, 2001) and 7 (CDSC, 1998) adults, respectively, in the UK.

Although many human illness outbreaks were traced to ground beef (USDA-APHIS-VS, 1997), the beef source (beef or dairy cattle) was not known in most cases. This is because ground beef is produced mainly from culled dairy and beef cattle and includes low-value cuts from finished steers or heifers. Cows culled because of health, age, or production reasons are a significant component of the hamburger consumed in the US; 6 million culled dairy cows enter the food chain as ground beef annually (Troutt and Osburn, 1997; National Cat- 
Table 1. Human infections with Escherichia coli $0157^{1}$ from dairy cattle.

\begin{tabular}{|c|c|c|c|c|c|c|}
\hline Country & Year & $\begin{array}{l}\text { Cases } \\
\text { (no.) }\end{array}$ & Age & Illness (no.) & $\begin{array}{l}\text { Infection } \\
\text { route }\end{array}$ & Reference \\
\hline \multicolumn{7}{|l|}{ US } \\
\hline WI & 1986 & 2 & $<13$ mo & $\mathrm{HUS}^{2}$ & Raw milk & Martin et al., 1986 \\
\hline \multirow[t]{2}{*}{ WA } & 1986 & 37 & Adults & $\begin{array}{l}\operatorname{HC}^{3}(\text { all }), \operatorname{HUS}(1), \text { and } \\
\operatorname{TTP}^{4}(3)\end{array}$ & Ground beef & Ostroff et al., 1990 \\
\hline & 1990 & 2 & Adults & HUS & Raw milk & Wells et al., 1991 \\
\hline OR & 1993 & 14 & Adults & Diarrhea & Raw milk & Keene et al., 1997 \\
\hline WI & 1998 & 55 & $15 \mathrm{mo}$ to $90 \mathrm{yr}$ & $\begin{array}{l}\text { Abdominal pain/bloody } \\
\text { diarrhea }\end{array}$ & Cheese & CDC, 2000 \\
\hline \multirow[t]{2}{*}{ PA } & 2000 & 47 & $<10 \mathrm{yr}$ & $\begin{array}{l}\text { Abdominal pain/bloody } \\
\text { diarrhea (all) and HUS (8) }\end{array}$ & $\begin{array}{l}\text { Visiting a dairy } \\
\text { farm }\end{array}$ & Crump et al., 2002 \\
\hline & & 4 & Adults & $\begin{array}{l}\text { Abdominal pain/bloody } \\
\text { diarrhea }\end{array}$ & & \\
\hline WA & 2000 & 5 & 2 to $14 \mathrm{yr}$ & $\begin{array}{l}\text { Abdominal pain/bloody } \\
\text { diarrhea (all) and HUS (1) }\end{array}$ & $\begin{array}{l}\text { Visiting a dairy } \\
\text { farm }\end{array}$ & $\begin{array}{l}\text { Georgia Division of } \\
\text { Public Health, } 2002\end{array}$ \\
\hline \multirow[t]{2}{*}{ Canada (Ontario) } & 1986 & 60 & $<5 \mathrm{yr}$ & $\begin{array}{l}\text { Abdominal pain/diarrhea } \\
\text { (all) and HUS (3) }\end{array}$ & Raw milk & Borczyk et al., 1987 \\
\hline & & 14 & Adults & Abdominal pain/diarrhea & & \\
\hline Canada (Alberta) & 1987 & 15 & Elderly & $\begin{array}{l}\text { Abdominal pain/bloody } \\
\text { diarrhea }\end{array}$ & Ground beef & Todd et al., 1993 \\
\hline \multirow[t]{2}{*}{ UK (England) } & 1991 & 11 & $<10 \mathrm{yr}$ & $\begin{array}{l}\text { Diarrhea or HC (all) and } \\
\text { HUS (5) }\end{array}$ & Yogurt & Morgan et al., 1993 \\
\hline & & 5 & Adults & Diarrhea or HC & & \\
\hline Canada (Ontario) & 1992 & 1 & $6 \mathrm{mo}$ & No signs of illness & $\begin{array}{l}\text { Raw milk or } \\
\text { animal/manure } \\
\text { contact }\end{array}$ & Wilson et al., 1996 \\
\hline \multirow[t]{2}{*}{ UK (England) } & 1993 & 4 & Children & $\begin{array}{l}\text { Abdominal pain (all) and } \\
\text { HUS (3) }\end{array}$ & Raw milk & Wall et al., $1996^{5}$ \\
\hline & & 3 & Adults & Abdominal pain & & \\
\hline \multirow[t]{2}{*}{ UK (Scotland) } & 1994 & 3 & Children & $\begin{array}{l}\text { Abdominal pain/bloody } \\
\text { diarrhea (2) and HUS (1) }\end{array}$ & Cheese & Reid, $2001^{5}$ \\
\hline & & 19 & Adults & $\begin{array}{l}\text { Abdominal pain/bloody } \\
\text { diarrhea }\end{array}$ & & \\
\hline UK (England) & 1996 & 3 & Adults & Abdominal pain/diarrhea & Raw milk & CDSC, $1996^{5}$ \\
\hline \multirow[t]{4}{*}{ Finland } & 1997 & 4 & $<11 \mathrm{yr}$ & $\begin{array}{l}\text { Bloody diarrhea (all) and } \\
\text { HUS (2) }\end{array}$ & $\begin{array}{l}\text { Raw milk or } \\
\text { animal/manure } \\
\text { contact }\end{array}$ & Lahti et al., 2002 \\
\hline & & 2 & $<11 \mathrm{yr}$ & Diarrhea & & \\
\hline & & 1 & A child & No signs of illness & & \\
\hline & & 1 & An adult & No signs of illness & & \\
\hline Czech Republic & 1998 & 2 & $<6 \mathrm{yr}$ & Bloody diarrhea and HUS & $\begin{array}{l}\text { Visiting a dairy } \\
\text { farm }\end{array}$ & $\begin{array}{l}\text { Bielaszewska et al., } \\
2000^{6}\end{array}$ \\
\hline Finland & 1998 & 1 & An adult & Bloody diarrhea & Raw milk & Lahti et al., 2002 \\
\hline UK (England) & 1998 & 7 & Adults & $\begin{array}{l}\text { Abdominal pain/diarrhea } \\
\text { (all) and HUS (4) }\end{array}$ & Cream & CDSC, $1998^{5}$ \\
\hline \multirow[t]{4}{*}{ UK (Scotland) } & 1998 & 1 & $3 \mathrm{yr}$ & Abdominal pain/diarrhea & Raw milk & Reid, 2001 \\
\hline & & 1 & $12 \mathrm{yr}$ & HUS & Cheese & \\
\hline & & 1 & An adult & Abdominal pain/diarrhea & Butter & \\
\hline & & 3 & Adults & $\begin{array}{l}\text { Abdominal pain/diarrhea } \\
\text { (all) and HUS/death (1) }\end{array}$ & Cheese & \\
\hline \multirow[t]{4}{*}{ UK (England) } & 1999 & 60 & Adults & Abdominal pain/diarrhea & Raw milk & CDSC, $1999 \mathrm{a}^{5}$ \\
\hline & 1999 & 3 & Adults & Abdominal pain/diarrhea & Cheese & CDSC, $1999 b^{5}$ \\
\hline & 2000 & 1 & A child & HUS & Raw milk & $\begin{array}{l}\text { International } \\
\text { Association of Milk, } \\
\text { Food, and } \\
\text { Environmental } \\
\text { Sanitarians, } 2000^{5}\end{array}$ \\
\hline & & 3 & Adults & Bloody diarrhea & & \\
\hline Austria & 2001 & 1 & $6 \mathrm{yr}$ & Bloody diarrhea and HUS & Raw milk & $\begin{array}{l}\text { Allerberger et al., } \\
2001^{6}\end{array}$ \\
\hline
\end{tabular}

\footnotetext{
${ }^{1}$ All isolates were $E$. coli $\mathrm{O} 157: \mathrm{H} 7$ unless indicated otherwise.

${ }^{2} \mathrm{HUS}=$ Hemolytic uremic syndrome.

${ }^{3} \mathrm{HC}=$ Hemorrhagic colitis .

${ }^{4} \mathrm{TTP}=$ Thrombotic thrombocytopenic purpura.

${ }^{5}$ The $E$. coli $\mathrm{O} 157$ isolates were not typed for the $\mathrm{H}$ antigen.

${ }^{6}$ A nonmotile E. coli $\mathrm{O} 157$ isolate.
} 
Table 2. Human infections with non-O157 Shiga toxin-producing Escherichia coli from dairy cattle.

\begin{tabular}{|c|c|c|c|c|c|c|c|}
\hline Country & Year & $\begin{array}{l}\text { Cases } \\
\text { (no.) }\end{array}$ & Age & $\begin{array}{l}\text { Illness } \\
\text { (no.) }\end{array}$ & Serotype & $\begin{array}{l}\text { Infection } \\
\text { route }\end{array}$ & Reference \\
\hline US (MT) & 1994 & 4 & Adults & $\begin{array}{l}\text { Abdominal } \\
\text { pain/bloody } \\
\text { diarrhea }\end{array}$ & O104:H21 & Raw milk & CDC, 1995 \\
\hline \multirow[t]{2}{*}{ Canada (Ontario) } & 1992 & 2 & $<2 \mathrm{yr}$ & $\begin{array}{l}\text { No signs of } \\
\text { illness }\end{array}$ & $\mathrm{O} 5: \mathrm{H}^{-1}$ or $\mathrm{O} 7: \mathrm{H} 4$ & \multirow[t]{2}{*}{$\begin{array}{l}\text { Raw milk or } \\
\text { animal/manure } \\
\text { contact }\end{array}$} & \multirow[t]{2}{*}{ Wilson et al., 1996} \\
\hline & & 6 & Adults & $\begin{array}{l}\text { No signs of } \\
\text { illness }\end{array}$ & $\begin{array}{l}\mathrm{O} 80: \mathrm{H}^{-}, \mathrm{O} 91: \mathrm{H} 14, \\
\text { O103:H2, O119:H25, } \\
\text { O132:H', or } \\
\text { O146:H21 }\end{array}$ & & \\
\hline France & $\begin{array}{l}1992- \\
1993\end{array}$ & 4 & $<15$ mo & $\begin{array}{l}\text { HUS }^{2} \text { (all) } \\
\text { and bloody } \\
\text { diarrhea (3) }\end{array}$ & Unknown & Cheese & Deschênes et al., 1996 \\
\hline Germany & 1997 & 1 & $2 \mathrm{yr}$ & HUS & $\mathrm{OUT}^{3}: \mathrm{H} 8$ & Raw milk & Gallien et al., 1997 \\
\hline
\end{tabular}

tlemen's Beef Association, 2001). Culled dairy cows account for $17 \%$ of the ground beef produced in the US (Troutt and Osburn, 1997). In New York State alone, culled dairy cows contribute 4.8 million $\mathrm{kg}$ of hamburger annually (Segelken, 1996). In general, it is difficult to trace a specific ground beef outbreak to dairy or beef cattle. The only 2 known dairy beef outbreaks are summarized in Table 1.

Contact with dairy farm environments through touching the cattle or their manure resulted in severe cases of $E$. coli O157:H7-related illnesses (HUS) in the US (Crump et al., 2002; Georgia Division of Public Health, 2002). The illnesses were associated with farm visitors, and no symptoms were reported for farm residents or employees (Crump et al., 2002). Visitors who washed their hands also did not become ill, indicating a protective effect of hand washing. Two severe cases attributable to visiting a dairy farm were also reported in the Czech Republic and were caused by $E$. coli O157: $\mathrm{H}^{-}$(Bielaszewska et al., 2000). As shown in Table 1 , responses to infection varied from no signs of illness (Wilson et al., 1996; Lahti et al., 2002) to bloody diarrhea and HUS (Lahti et al., 2002) and reflected the immunity status of the affected individuals (mostly children). In general, previous exposure to farm animals is known to decrease the risk of infection with STEC (Wilson et al., 1997). In a study of numerous environmental sites on dairy farms (Blanco et al., 2001), evidence of STEC was found in composite samples of calf feeders (19\%), calf-barn surfaces (18\%), cow feeders (15\%), and cow-barn surfaces (11\%). Therefore, contaminated farm environments may remain sources of STEC infection for several months.

Infections with non-O157 STEC from dairy cattle are summarized in Table 2. Most of those were traced to consumption of raw milk, as was the case with the US outbreak (CDC, 1995). The remaining raw milk outbreaks occurred in Canada (Wilson et al., 1996) and Germany (Gallien et al., 1997). Although E. coli $\mathrm{O} 5: \mathrm{H}^{-}$ and O103:H2 serotypes were not shown to cause any signs of illness (Table 2), they are known to cause HUS (WHO, 1998). Several outbreaks were also attributed to consumption of cheeses (those made from unpasteurized milk) in Sweden, the UK, the US (Adams and Motarjemi, 1999), and France (Deschênes et al., 1996). Brie cheese was responsible for the outbreaks in Sweden and the US, whereas local cheeses were responsible for the remaining ones. Contact with dairy cattle manure was also the cause of Canadian outbreaks of STEC $\left(\mathrm{O} 5: \mathrm{H}^{-}\right.$and $\left.\mathrm{O} 7: \mathrm{H} 4\right)$ infections (Wilson et al., 1996).

\section{STEC SEROTYPES FROM MILK AND DAIRY PRODUCTS}

Studies on contamination of milk or its products with E. coli, in general, have been limited. Testing raw milk and cheese samples (500 and 739, respectively) revealed low levels ( $<20 \mathrm{cfu} / \mathrm{g}$ ) of $E$. coli contamination (Coia et al., 2001). Detection of STEC in raw milk, milk filters, and cheeses (Table 3) was reported in Canada, Belgium, Germany, the UK, and the US (WHO, 1998). Padhye and Doyle (1991) reported that E. coli O157:H7 was detected in raw milk and cheese. Two STEC serotypes (O91:H21 and an untypeable $\mathrm{O}$ antigen [OUT]: $\left.\mathrm{H}^{-}\right)$and members of the 091 and 0113 serogroups were isolated from raw milk and cheese (Table 3). None of these isolates is known to cause human illnesses attributable to the consumption of dairy foods. However, E. coli O91:H21 and OUT: $\mathrm{H}^{-}$were isolated from patients with HUS and bloody diarrhea, respectively (WHO, 1998). 
Table 3. Shiga toxin-producing Escherichia coli from raw milk, milk filters, and cheese.

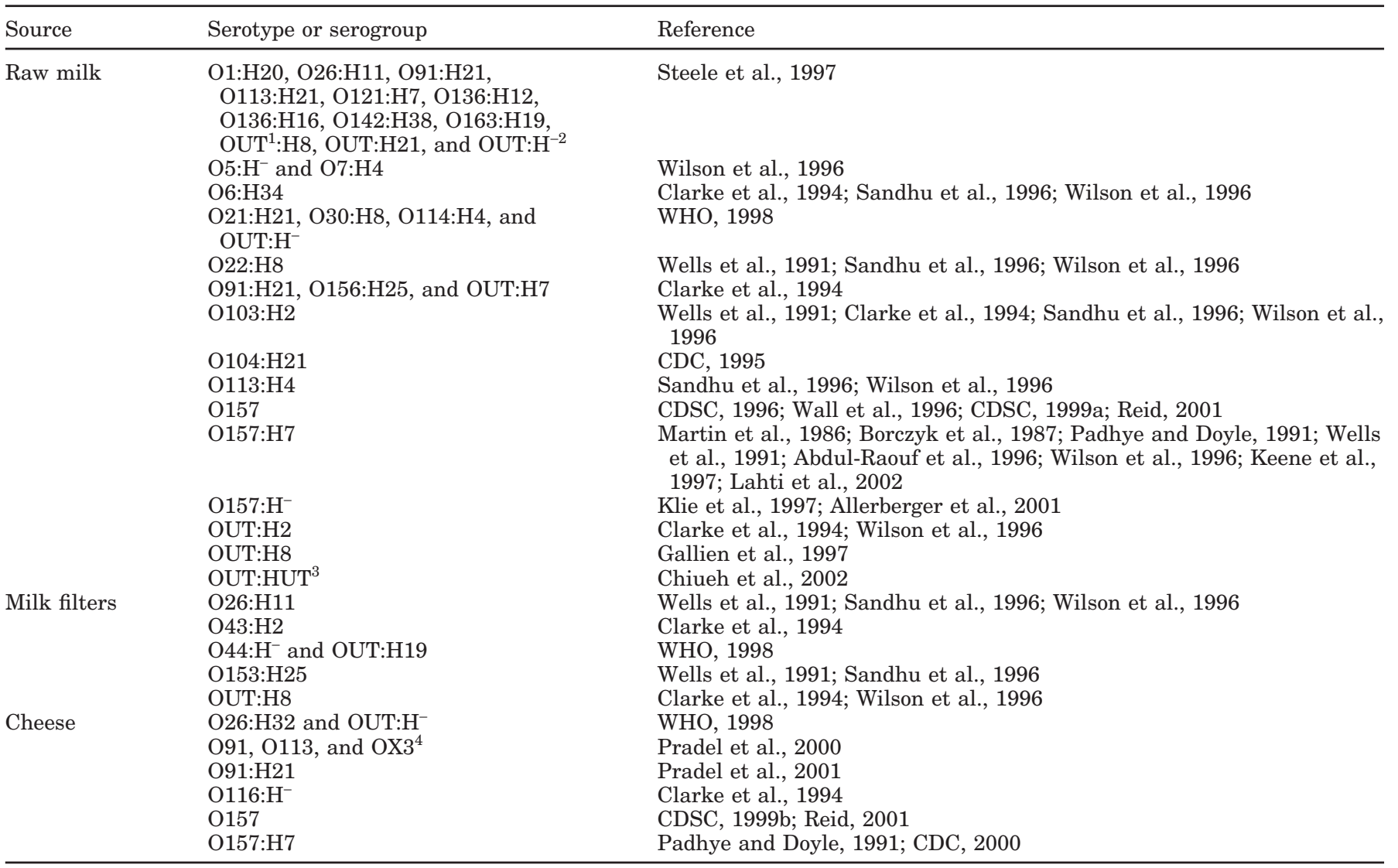

${ }^{1} \mathrm{OUT}=\mathrm{An}$ untypeable $\mathrm{O}$ antigen.

${ }^{2} \mathrm{H}^{-}=$A nonmotile $E$. coli isolate.

${ }^{3} \mathrm{HUT}=$ An untypeable $\mathrm{H}$ antigen.

${ }^{4} \mathrm{OX} 3$ = Provisional designation for the O174 antigen.

Interestingly, the $E$. coli OUT:H8 found in milk filters (Table 3 ) is known to cause HUS (Table 2). Of E. coli isolates (O6:H10, O26:H32, $\mathrm{O} 116: \mathrm{H}^{-}$, and $\left.\mathrm{OUT}: \mathrm{H}^{-}\right)$ found in Canadian cheeses (WHO, 1998), 2 serotypes (O26:H32 and OUT: $\mathrm{H}^{-}$) are known to cause HUS (WHO, 1998). Recently, several STEC strains (members of the O8, O103, O156, and O157 serogroups) were isolated from raw milk tanks in the UK (McKee et al., 2003). Although these isolates had 1 ( $s t x_{1}$ in 0103 and $s t x_{2}$ in $\mathrm{O} 8$ and $\mathrm{O} 156)$ or 2 (stx $x_{2}$ and eae in $\mathrm{O} 157$ ) virulence factors, only members of the $\mathrm{O} 103$ and $\mathrm{O} 157$ serogroups are known to cause human illnesses (WHO, 1998).

\section{DAIRY CATTLE AS RESERVOIRS OF STEC}

Although STEC are not host specific, they are more prevalent in ruminants than in other animals (Riemann and Cliver, 1998). In addition, human illnesses caused by STEC infection have been traced mostly to cattle (Dean-Nystrom et al., 1997). Therefore, cattle (Martin et al., 1986; Wilson et al., 1992; Chapman et al., 1993), including dairy cows, heifers, and calves (Hancock et al., 1994; Zhao et al., 1995; Besser et al., 1997), have been considered reservoirs of STEC. Zhao et al. (1995) estimated that 22 to $50 \%$ of the US dairy farms are contaminated with $E$. coli O157:H7. Higher estimates should be considered for STEC prevalence when taking into account other serotypes. The wide distribution of STEC on dairy farms was documented (Rahn et al., 1998) in the high prevalence rates reported for cows ( 58 of $274 ; 21.2 \%$ ) and calves ( 68 of $135 ; 50.4 \%$ ). In a recent study of 3 Japanese dairy farms (Ezawa et al., 2004), the prevalence rates of $E$. coli 0157 were $33.7,18.5$, and $0 \%$ for heifers, cows, and calves, respectively. The high prevalence rate in heifers was attributed to their close contact during grazing. Other studies (Wells et al., 1991, 1992) illustrated the presence of a wide range of STEC serotypes in dairy cattle at different stages of production. Testing 1266 fecal samples from cows, heifers, and calves from 22 farms, a stockyard, and a packing plant (Wells et al., 1991) revealed the presence of $E$. coli $\mathrm{O} 157: \mathrm{H} 7, \mathrm{O} 157: \mathrm{H}^{-}$, and 27 other non- 
O157 serotypes $\left(\mathrm{O} 10: \mathrm{H}^{-}, \mathrm{O} 15: \mathrm{H} 27, \mathrm{O} 22: \mathrm{H} 8, \mathrm{O} 22: \mathrm{H} 40\right.$, $\mathrm{O} 25: \mathrm{H}^{-}, \mathrm{O} 26: \mathrm{H} 11, \mathrm{O} 45: \mathrm{H} 2, \mathrm{O} 45: \mathrm{H}^{-}, \mathrm{O} 76: \mathrm{H} 21, \mathrm{O} 84: \mathrm{H} 2$, $\mathrm{O} 84: \mathrm{H}^{-}, \quad \mathrm{O} 103: \mathrm{H} 2, \quad \mathrm{O} 103: \mathrm{H}^{-}, \quad \mathrm{O} 111: \mathrm{H}^{-}, \quad \mathrm{O} 116: \mathrm{H} 21$, O121:H7, O145: $\mathrm{H}^{-}$, O153:H25, O163:H19, O171:H2, OX3 [the provisional designation for the O174 antigen]:H21, OX3: $\mathrm{H}^{-}$, OR [a rough $\mathrm{O}$ antigen]:H2, OR:H8, $\mathrm{OR}: \mathrm{H}^{-}, \mathrm{OUT}: \mathrm{H}^{-}$, and OUT:HUT [an untypeable $\mathrm{H}$ antigen]). Except for no detection of $E$. coli $\mathrm{O} 157: \mathrm{H} 7$, a similar distribution of non-O157 STEC was found when 1790 fecal samples from dairy cows and calves were tested (Wilson et al., 1992). The STEC strains included O2:HUT, O3:HUT, O4:H7, O4:H16, O4:H- O6:HUT, O8:H8, O8:H16, O8: $\mathrm{H}^{-}, \mathrm{O} 8: \mathrm{HUT}, \mathrm{O} 9: \mathrm{H}^{-}, \mathrm{O} 11: \mathrm{HUT}$, $\mathrm{O} 15: \mathrm{H}^{-}, \mathrm{O} 22: \mathrm{H} 1, \mathrm{O} 22: \mathrm{H} 8, \mathrm{O} 26: \mathrm{H}^{-}, \mathrm{O} 32: \mathrm{H} 7, \mathrm{O} 32: \mathrm{H} 16$, $\mathrm{O} 32: \mathrm{H}^{-}$， O32:HUT, O40:HUT, O43:H2， O43:H6, $\mathrm{O} 43: \mathrm{H} 12, \quad \mathrm{O} 82: \mathrm{H}^{-}, \quad \mathrm{O} 87: \mathrm{H}^{-}, \quad \mathrm{O} 103: \mathrm{H} 2, \quad \mathrm{O} 103: \mathrm{H} 6$, O103:H12， O103:H16， O103:H39， O103:HUT, O106:HUT, O109:H16, O111: $\mathrm{H}^{-}, \mathrm{O} 113: \mathrm{H}^{-}, \mathrm{O} 117: \mathrm{H}^{-}$,

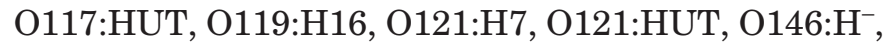
O153:H7, O153:H32, O153:H-, O153:HUT, O163:HUT,

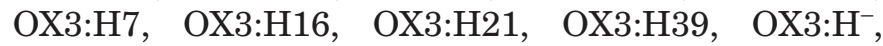
OX3:HUT, OX8 [a provisional designation for a new $\mathrm{O}$ antigen]:HUT, OUT:H2, OUT:H3, OUT:H6, OUT:H7, OUT:H8, OUT:H12, OUT:H16, OUT:H21, OUT:H40, OUT: $\mathrm{H}^{-}$, and OUT:HUT. Similar trends were also found in Japan (Tada et al., 1992; Furuhata et al., 1999), where members of the O26, O111, O145, and 0157 serogroups (Tada et al., 1992) and 84 non-O157 STEC serotypes (Furuhata et al., 1999) were detected in dairy cattle feces. Furuhata et al. (1999) indicated that different serotypes were associated with specific geographical locations or climates and suggested that certain STEC serotypes may have resistance to hot or cold climates. With regard to sex effects on STEC shedding by dairy cattle, only one study was found (Montenegro et al., 1990). Various STEC serotypes $\left(\mathrm{O} 3: \mathrm{H}^{-}, \mathrm{O} 10: \mathrm{H} 21\right.$, O22:H8, O39:H40， O75:H8， O82:H8， O82:H40, O91:H10, O104:H21, O105:H18, O113:H21, O116:H21, O126:H20, O126:H21, O136:H12, O139:H8, O156:H21, O157:H7, OR:H18, OUT:H16, and OUT:H29) were recovered from 17 and $9 \%$ of the 47 cows and 212 bulls tested, respectively. To better define dairy cattle as reservoirs of STEC, published reports on STEC prevalence in dairy cattle were evaluated.

\section{PREVALENCE OF STEC IN DAIRY CATTLE}

Prevalence rates of STEC in dairy cattle are summarized in Table 4. With 2 exceptions (Mechie et al., 1997; Bonardi et al., 1999), the prevalence rates of $E$. coli O157:H7 were based on one-time sampling of cattle feces. In these 2 studies, multiple samples (monthly for 15 mo or $1 \mathrm{yr}$, respectively) were tested. In Canada (Jackson et al., 1998), a very high prevalence rate (59 of $95 ; 62.1 \%$ ) was found in a dairy farm that was associated with a child infection with $E$. coli $\mathrm{O} 157: \mathrm{H} 7$. In the US, $E$. coli $\mathrm{O} 157: \mathrm{H} 7$ prevalence rates ranged from 0.2 to $8.4 \%$ for cows, from 1.6 to $3.0 \%$ for heifers, and from 0.4 to $40.0 \%$ for calves. In Canada, Italy, Japan, and the UK, the corresponding ranges of $E$. coli $\mathrm{O} 157: \mathrm{H} 7$ prevalence rates were 0.3 to $16.1 \%, 10.0$ to $14.1 \%$, and 1.7 to $48.8 \%$, respectively. These data emphasized the significant impact of animal age on epidemiology of $E$. coli $\mathrm{O} 157: \mathrm{H7}$ as illustrated in the higher prevalence rates for younger (2- to 24-mo old) than for older cattle. Testing dairy cattle on 10 Dutch farms (Heuvelink et al., 1998) revealed prevalence rates of $E$. coli O157:H7 ranging from 0.8 to $22 \%$, with calves (4- to 12 -mo old) having the highest rate $(21 \%)$. High prevalence rates were also reported for young beef cattle (Hancock et al., 1997c) and were attributed to the greater susceptibility to colonization for calves and heifers than for cows (Hancock et al., 1998). Prevalence rates of $E$. coli O157:H7 among dairy calves also appear to be affected by age. For example, the prevalence rate increased from $1.4 \%$ ( 6 of 423) before weaning to $4.8 \%$ ( 25 of 518 ) after weaning (Garber et al., 1995). Testing a large number of calves from 60 dairy herds in Washington State revealed that $E$. coli $\mathrm{O} 157: \mathrm{H} 7$ was more prevalent in weaned (7 of $1083 ; 0.65 \%$ ) than in unweaned ( 0 of 649 ; 0\%) calves (Hancock et al., 1994).

Factors that may affect the prevalence of $E$. coli O157:H7 in dairy cows were evaluated (Hancock et al.1994; Fitzgerald et al., 2003). In the study by Hancock et al. (1994), similar prevalence rates were reported for lactating ( 2 of $1273 ; 0.16 \%$ ) and dry ( 1 of 477 ; $0.21 \%$ ) cows. In contrast, a higher prevalence rate $(43 \%$ vs. $22 \%$ ) was reported for lactating cows than for dry cows (Fitzgerald et al., 2003). The time of fecal sampling was shown (Fitzgerald et al., 2003) to affect the number of dry cows shedding $E$. coli $\mathrm{O} 157: \mathrm{H} 7$ (28\% for a.m. vs. $17 \%$ for p.m.) but not the lactating cows (average, $43 \%$ ). Parity and DIM did not influence the number of cows shedding E. coli O157:H7 (Fitzgerald et al., 2003). The higher prevalence rates reported by Fitzgerald et al. (2003) could be attributed to the hot weather during the time of fecal sampling (August) in New Mexico. In the study by Hancock et al. (1994), however, the reported prevalence rates were average values of fecal testing of different dairy farms over a 1-yr investigation in Washington State.

Prevalence rates of $E$. coli $\mathrm{O} 157: \mathrm{H} 7$ in culled dairy cows have been variable. For example, prevalence rates ranging from $0.5 \%$ in Canada (Clarke et al., 1994) to $16.1 \%$ in the UK (Chapman et al., 1997) were reported. The $16.1 \%$ prevalence rate (Chapman et al., 1997) was much higher than the rates (1 to $2 \%$ ) reported for younger dairy cows in the UK (Chapman et al., 1993) 
or in the US (Hancock et al., 1994). Prevalence rates for culled dairy cows ranged from 0.9 to $3 \%$ in New York State (USDA-APHIS-VS, 1996b). Based on data from 91 dairy farms, Garber et al. (1999) showed a higher prevalence rate $(2.8 \%$ vs. $0.9 \%)$ for $E$. coli O157:H7 in culled cows than in those in production. Rice et al. (1997) tested fecal samples from culled dairy cows on the farm (205 cows from 19 herds) and at slaughter (103 cows from 15 herds) in Idaho, Oregon, and Washington State and reported that 3.4 and 3.9\% of the cows on the farm and at slaughter, respectively, were positive for $E$. coli O157:H7. Dairy cattle with downer cow syndrome are those suffering from assorted maladies (e.g., mastitis, calving paralysis, and milk fever) and/or injuries (e.g., during transport) that render them immobile to various degrees (Correa et al., 1993). If their condition does not improve, they are culled from the production herd (Faith et al., 1996; Troutt and Osburn, 1997) and enter the food chain as ground beef. As a result, downer dairy cows harboring STEC at slaughter can be a health risk to humans. This potential risk was recently evaluated at 2 packing plants in Wisconsin over a 6-mo (May to October) period (Byrne et al., 2003). The prevalence rate was higher for downer (10 of 203; $4.9 \%$ ) than for healthy (3 of $201 ; 1.5 \%$ ) cows that were harvested at the same time and were from similar geographical locations.

Prevalence rates of non-O157 STEC in dairy cattle are also summarized in Table 4. Multiple sampling (monthly over a 1-yr period) of cattle feces was used in 2 studies (Hancock et al., 1997a; Conedera et al., 2001) but one-time sampling was used in the others. Worldwide, the prevalence rates ranged from 0.4 to $52.0 \%$ for cows, from 1.7 to $74.0 \%$ for heifers, and from 1.3 to $68.7 \%$ for calves. Non-O157 STEC were more prevalent in dairy cattle than $E$. coli $\mathrm{O} 157$ (Table 4). In addition to detecting strains that belonged to $39 \mathrm{O}$ serogroups, a total of 77 STEC serotypes were isolated from dairy cattle feces (Table 4). Of these, $15(\mathrm{O} 2: \mathrm{H} 29, \mathrm{O} 22: \mathrm{H} 8$, O26:H11，O103:H2，O103: $\mathrm{H}^{-} ， \mathrm{O} 105: \mathrm{H} 18 ， \mathrm{O} 111: \mathrm{H} 8$, O111: $\mathrm{H}^{-}, \mathrm{O} 113: \mathrm{H} 21, \mathrm{O} 145: \mathrm{H}^{-}, \mathrm{O} 153: \mathrm{H} 25, \mathrm{O} 163: \mathrm{H} 19$, OX3:H21, OUT:H2, and OUT:H25) are known to cause HUS and $20\left(\mathrm{O} 7: \mathrm{H} 4, \mathrm{O} 15: \mathrm{H} 27, \mathrm{O} 22: \mathrm{H} 40, \mathrm{O} 22: \mathrm{H}^{-}\right.$, $\mathrm{O} 25: \mathrm{H}^{-}, \mathrm{O} 45: \mathrm{H} 2, \mathrm{O} 45: \mathrm{H}^{-}, \mathrm{O} 70: \mathrm{H} 11, \mathrm{O} 84: \mathrm{H} 2, \mathrm{O} 91: \mathrm{H}^{-}$, O113:H2，O113:H4， O119: $\mathrm{H}^{-}, \mathrm{O} 125: \mathrm{H}^{-}, \mathrm{O} 146: \mathrm{H} 21$, O171:H2, OR:H- OUT:H18, OUT:H21, and OUT:H ${ }^{-}$) are known to cause other illnesses (WHO, 1998).

In contrast to the $E$. coli $\mathrm{O} 157: \mathrm{H} 7$ data, there was no clear age effect on the prevalence of non-O157 STEC (Table 4). Interestingly, Nielsen et al. (2002) reported

Table 4. Prevalence of Shiga toxin-producing Escherichia coli (STEC) in dairy cattle.

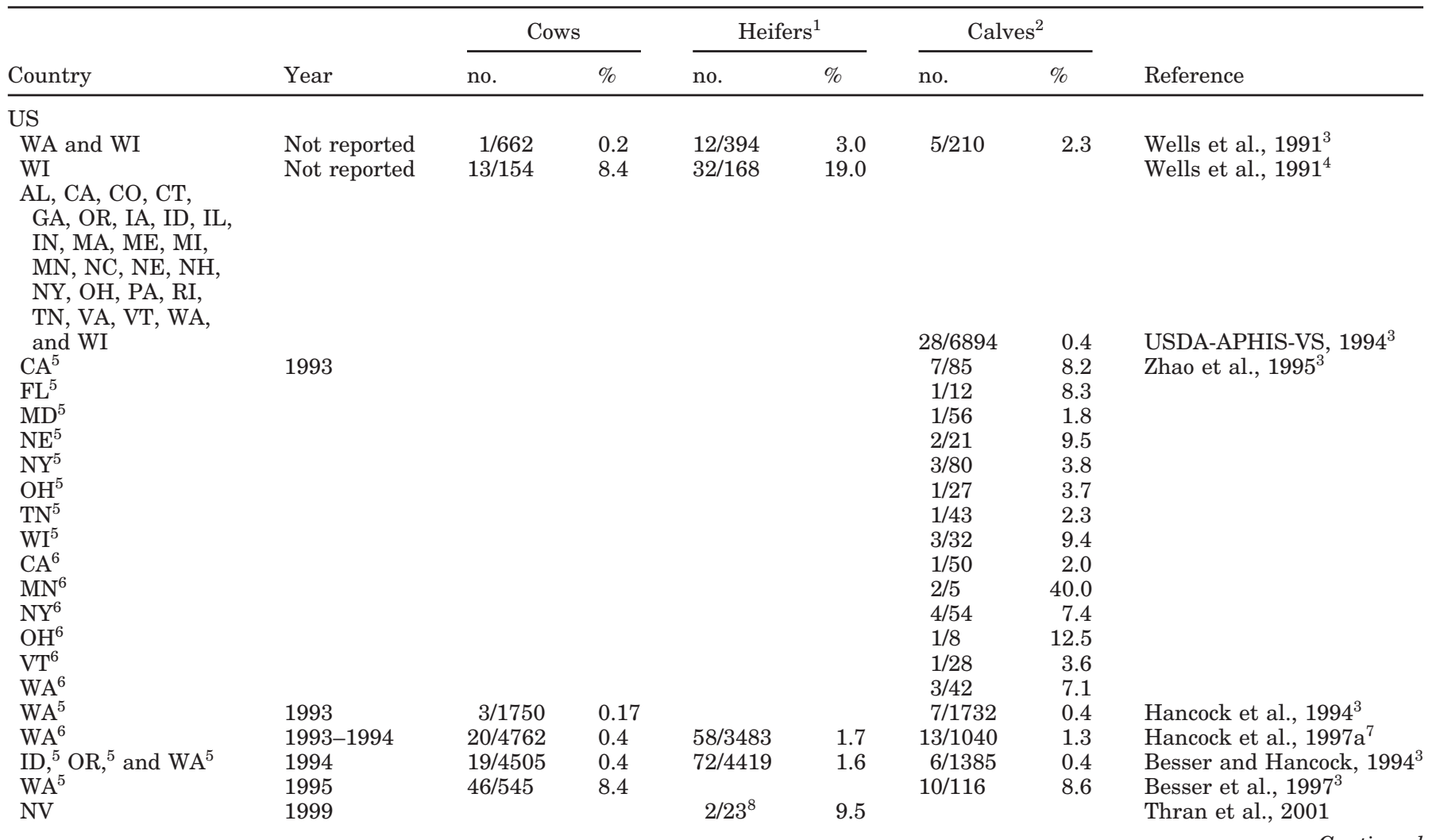


Table 4 (Continued). Prevalence of Shiga toxin-producing Escherichia coli (STEC) in dairy cattle.

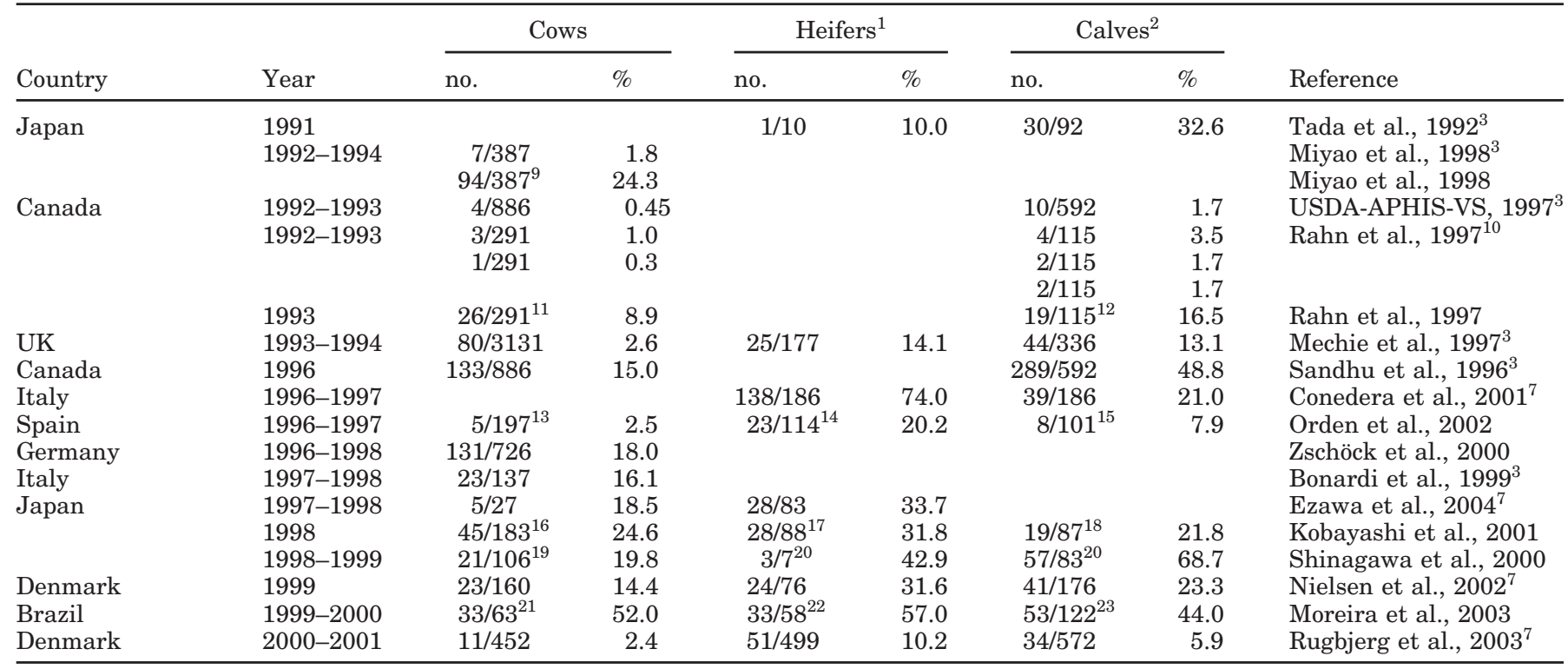

${ }^{1} 6$ mo to 2 yr old.

${ }^{2}<6$ mo old.

${ }^{3}$ Studies tested only for E. coli O157:H7.

${ }^{4}$ The prevalence rate for the heifers included all animals that were $<2 \mathrm{yr}$ old. The cattle shed STEC isolates belonging to various serotypes $\left(\mathrm{O} 10: \mathrm{H}^{-}\right.$[a nonmotile isolate], O15:H27, O22:H8, O22:H40, O25: $\mathrm{H}^{-}, \mathrm{O} 26: \mathrm{H} 11, \mathrm{O} 45: \mathrm{H} 2, \mathrm{O} 45: \mathrm{H}^{-}, \mathrm{O} 76: \mathrm{H} 21, \mathrm{O} 84: \mathrm{H} 2, \mathrm{O} 84: \mathrm{H}^{-}, \mathrm{O} 103: \mathrm{H} 2$, $\mathrm{O} 103: \mathrm{H}^{-}, \mathrm{O} 111: \mathrm{H}^{-}, \mathrm{O} 116: \mathrm{H} 21, \mathrm{O} 121: \mathrm{H} 7, \mathrm{O} 145: \mathrm{H}^{-}, \mathrm{O} 153: \mathrm{H} 25, \mathrm{O} 157: \mathrm{H}^{-}, \mathrm{O} 163: \mathrm{H} 19, \mathrm{O} 171: \mathrm{H} 2, \mathrm{OX} 3$ [the provisional designation for the $\mathrm{O} 174$

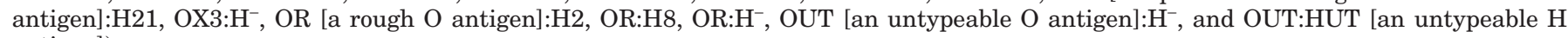
antigen]).

${ }^{5}$ Control herds (herds in which E. coli O157 was not previously isolated).

${ }^{6}$ Case herds (herds in which E. coli O157 was previously isolated).

${ }^{7}$ The $E$. coli $\mathrm{O} 157$ isolates were not typed for the $\mathrm{H}$ antigen.

${ }^{8}$ One heifer shed STEC isolates belonging to $E$. coli $\mathrm{O} 26: \mathrm{H}^{-}$, and the other heifer shed an untypeable isolate.

${ }^{9}$ The cows shed STEC isolates belonging to various serotypes $\left(\mathrm{O} 2: \mathrm{H} 25, \mathrm{O} 2: \mathrm{H} 29, \mathrm{O} 16: \mathrm{H} 2, \mathrm{O} 16: \mathrm{H} 21, \mathrm{O} 22: \mathrm{H} 8, \mathrm{O} 22: \mathrm{H}^{-}, \mathrm{O} 42: \mathrm{H} 25, \mathrm{O} 45: \mathrm{H} 8\right.$,

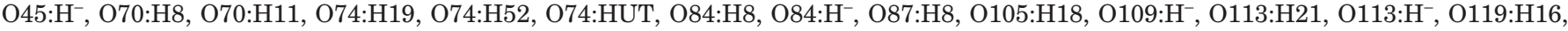
O132:H2, O136:H1, O136:H16, O145:H25, O145:H- O146:H21, O153:H19, O153:H25, O153:HUT, O156:H25, OUT:H7, OUT:H8, OUT:H16, OUT:H18, OUT:H19, OUT: $\mathrm{H}^{-}$, and OUT:HUT) with $\mathrm{O} 45: \mathrm{H} 8, \mathrm{O} 45: \mathrm{H}^{-}$, and $\mathrm{O} 145: \mathrm{H}^{-}$being the most frequently isolated serotypes.

${ }^{10}$ The prevalence data as illustrated in the 3 consecutive rows were based on 3 fecal samplings $(0,1$, and 3 mo, respectively) of the same herd. No animals tested positive at more than one sampling time.

${ }^{11}$ The cows shed STEC isolates belonging to the serotypes O2:H29, O15:H7, O98:H25, O111:H8, O113:H2, O119: $\mathrm{H}^{-}, \mathrm{O} 153: \mathrm{H} 25$,

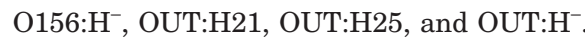

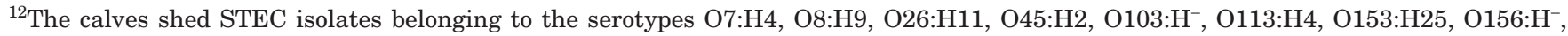
OUT:H2, OUT:H4, OUT21, and OUT:H'.

${ }^{13}$ Each cow shed a STEC isolate that belonged to a different serogroup (O84, O87, O110, O113, and O136).

${ }^{14}$ The serogroups of the STEC isolates and the number of heifers shedding these isolates were O2 (3), O5 (4), O8 (5), O21 (1), O22 (5), O74 (1), O91 (1), O98 (2), O113 (4), O116 (1), O172 (4), O174 (3), O175 (4), and OUT (11).

${ }^{15}$ The serogroups of the STEC isolates and the number of calves shedding these isolates were O4 (2), O8 (2), O23 (3), O103 (3), O111 (5), and $\mathrm{O} 174(1)$.

${ }^{16}$ The serogroups of the STEC isolates and the number of cows shedding these isolates were O8 (1), O15 (4), O22 (2), O26 (4), O38 (2), O55 (1), O73 (1), O84 (4), O88 (1), O103 (2), O104 (1), O111 (2), O113 (3), O116 (2), O125 (1), O136 (2), O153 (2), O157 (1), O158 (1), O163 (1), and OUT (7).

${ }^{17}$ The serogroups of the STEC isolates and the number of heifers shedding these isolates were O1 (1), O2 (1), O8 (4), O22 (2), O26 (1), O38 (1), O84 (1), O103 (1), O113 (2), O116 (3), O119 (2), O123 (1), O136 (1), and OUT (7).

${ }^{18}$ The serogroups of the STEC isolates and the number of calves shedding these isolates were O8 (3), O26 (4), O28 (1), O84 (1), O113 (3), O116 (1), O136 (1), O163 (1), and OUT (4).

${ }^{19}$ The serogroups of the STEC isolates were O26, O111, and O157.

${ }^{20}$ The STEC isolates were untypeable.

${ }^{21} \mathrm{STEC}$ isolates that belonged to the serotypes $\mathrm{O} 91: \mathrm{H}^{-}$and $\mathrm{O} 157: \mathrm{H}^{-}$.

${ }^{22}$ The heifers (12 to 24 mo old) shed STEC isolates that belonged to the $\mathrm{O} 157: \mathrm{H}^{-}$serotype.

${ }^{23}$ The calves (<12 mo old) shed STEC isolates belonged to the serotypes $\mathrm{O} 29: \mathrm{H}^{-}, \mathrm{O} 91: \mathrm{H}^{-}, \mathrm{O} 112: \mathrm{H}^{-}, \mathrm{O} 119: \mathrm{H}^{-}, \mathrm{O} 125: \mathrm{H}^{-}$, and $\mathrm{O} 157: \mathrm{H}^{-}$. 
variations in prevalence of non-O157 STEC within Danish dairy calves. A higher prevalence rate $(8.6 \%$ vs. $0.7 \%$ ) was found for older (2 to $6 \mathrm{mo}$ ) than for younger $(<2 \mathrm{mo})$ calves. Rugbjerg et al. (2003) also reported a higher prevalence rate ( $11.8 \%$ vs. $2.1 \%$ ) in older (3 to $4 \mathrm{mo}$ ) than in younger ( 1 to $2 \mathrm{mo}$ ) calves.

\section{PREVALENCE OF STEC IN RAW MILK}

Prevalence of STEC in raw milk was determined in a limited number of studies focusing on $E$. coli $\mathrm{O} 157: \mathrm{H} 7$ in bulk tanks (Wells et al., 1991; Murinda et al., 2002). In the US, a low prevalence rate ( 2 of $268 ; 0.75 \%$ ) was reported in Tennessee (Murinda et al., 2002) and a relatively higher rate ( 1 of $23 ; 4.3 \%$ ) was reported in Wisconsin and Washington State (Wells et al., 1991). Similar ( 2 of $35 ; 5.7 \%)$ and higher ( 6 of $37 ; 16.2 \%)$ prevalence rates were reported in the UK (Mechie et al., 1997) and Canada (Cardinal, 1993), respectively. A 2yr study of bulk milk in the UK (McKee et al., 2003) revealed a lower prevalence rate for STEC, in general, than those reported for $E$. coli O157:H7 (Wells et al., 1991; Cardinal, 1993; Mechie et al., 1997). The presumed route of STEC transmission to raw milk is fecal contamination during milking. This could be eliminated by improving sanitation during the milking process, as shown in a Taiwanese study (Chiueh et al., 2002). Raw milk samples from 407 cows tested negative for STEC, although 8 cows in the production herd tested positive (Chiueh et al., 2002).

\section{DAIRY CATTLE AS TRANSIENT CARRIERS OF STEC}

Prevalence rates of STEC in cattle have significant fluctuations over time (Hancock et al., 1998). Repeated fecal testing of cattle herds demonstrated that STEC are, at least occasionally, present on most farms (Hancock et al., 1997a, b). In general, cattle have not been reported as long-term carriers of STEC, and fecal shedding has not been associated with any cattle disease (Garber et al., 1995; Hancock et al., 1997b,c). Studies with dairy cattle showed the transient presence of $E$. coli O157:H7 (Hancock et al., 1994; 1997a). In an initial study (Hancock et al., 1994), E. coli O157:H7 was found on 5 of the 60 dairy farms that were sampled once. In a following study (Hancock et al., 1997a), 8 of the initially negative farms were sampled monthly for 3 to $12 \mathrm{mo}$, and $E$. coli $\mathrm{O} 157: \mathrm{H} 7$ was detected in 4 of those farms. It was concluded, therefore, that repeated sampling is needed to establish an accurate prevalence status of STEC.

Fecal shedding of STEC by dairy cattle has been shown to follow a seasonal trend. In the US, the highest prevalence rates of $E$. coli $\mathrm{O} 157: \mathrm{H} 7$ in dairy cattle were in warm weather (Hancock et al., 1997a,b; Garber et al., 1999), which is consistent with the timing of most human illness outbreaks (USDA-APHIS-VS, 1997). Monthly fecal sampling of dairy cattle in Idaho, Oregon, and Washington State (Hancock et al., 1997b) over a 6-mo period (July to December) revealed a sharp decline in $E$. coli $\mathrm{O} 157: \mathrm{H} 7$ prevalence in cold weather (November and December). An investigation of E. coli O157 on 9 dairy herds for 13 mo revealed prevalence rates that were several times higher in warm (June to October) than in cold (December to March) weather (Hancock et al., 1997a). The prevalence of $E$. coli O157:H7 peaked at $2.6 \%$ in June and was lowest $(0 \%)$ in December. In another study covering 20 states (CA, FL, ID, IL, IN, IA, KY, MI, MN, MO, NM, NY, OH, OR, PA, TN, TX, VT, WA, and WI), Garber et al. (1999) tested 4361 fecal samples from cows on 91 dairy farms over a 6-mo period (February to July) and reported a higher prevalence rate $(52.9 \%$ vs. $7.0 \%)$ in the summer than in the spring. Herds in the Southern states had a higher prevalence rate $(61.9 \%$ vs. $12.9 \%)$ than those in the Northern states. Hancock et al. (1997b) observed a significant correlation between multiple fecal testing of dairy herds and prevalence of $E$. coli $\mathrm{O} 157: \mathrm{H} 7$ and reported that some herds had tendencies to have higher or lower prevalence rates that were somewhat stable over time.

In a 1-yr study, similar seasonal effects on $E$. coli O157:H7 prevalence in dairy cows, heifers, and calves were detected in Canada, Denmark, Italy, and the UK. In the UK (Mechie et al., 1997), testing of 3593 fecal samples showed the highest prevalence rates (average, $8.3 \%$ ) to occur from May to July and the lowest rate (0\%) to occur from December to April. In Denmark (Rugbjerg et al., 2003), testing of 1706 fecal samples also showed a higher prevalence rate in summer than in winter (9.9\% vs. $2.9 \%)$. In Northern Italy (Bonardi et al., 1999), testing of 450 fecal samples revealed a higher prevalence rate $(17.5 \%$ vs. $2.9 \%)$ in the warm months (April to October) than in the cold months (November to January). In the same region (Conedera et al., 2001), testing of 650 fecal samples showed higher prevalence rates in August and September (average, 20\%) than in January and February (average, 15\%). In Canada (Van Donkersgoed et al., 1999), testing of 1247 fecal samples from culled cows at slaughter also showed $E$. coli O157:H7 to be most prevalent from June to August. Except for one investigation (Thran et al., 2001), no studies evaluating prevalence of non-O157 STEC over time were found. Testing fecal samples from 23 heifers over $1 \mathrm{yr}$ resulted in detecting STEC only during winter at a prevalence rate of 9.5\% (Thran et al., 2001). Interestingly, the STEC isolates belonged to 2 non-O157 serotypes $\left(\mathrm{O} 26: \mathrm{H}^{-}\right.$and OUT:HUT). 
Table 5. Virulence factors ${ }^{1}$ in Escherichia coli $0157^{2}$ from dairy cattle.

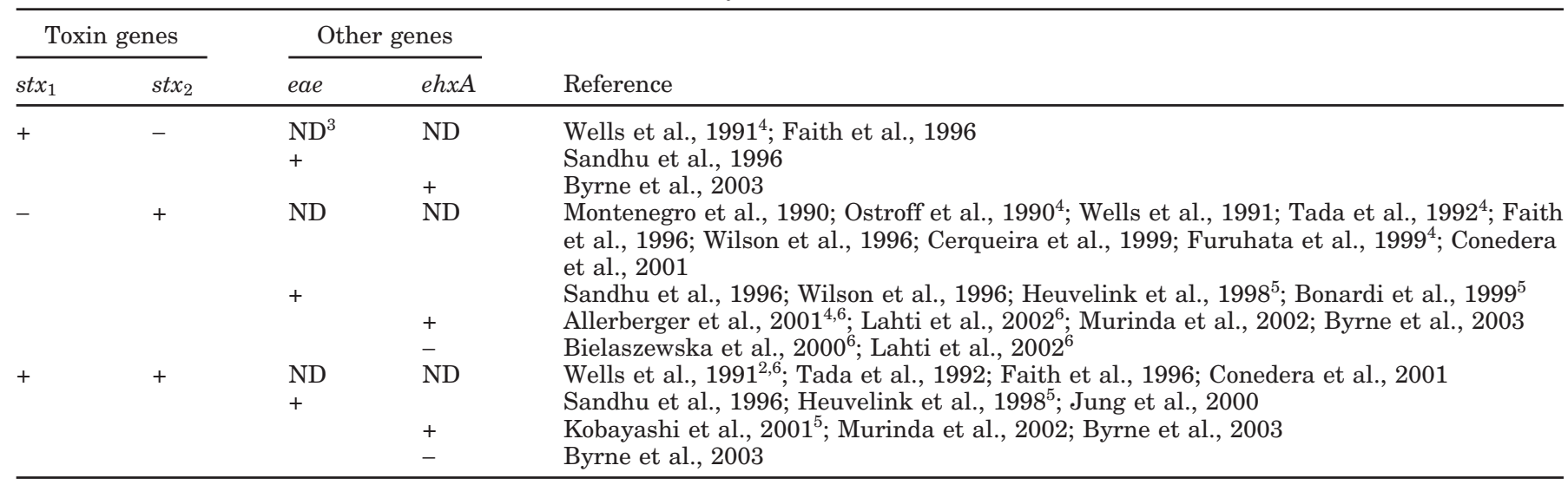

${ }^{1}$ The virulence factors include Shiga toxin $1\left(s t x_{1}\right)$, Shiga toxin $2\left(s t x_{2}\right), E$. coli attaching and effacing (eae), and enterohemolysin $(e h x A)$ genes.

${ }^{2}$ All isolates were $E$. coli $\mathrm{O} 157: \mathrm{H} 7$ unless indicated otherwise.

${ }^{3} \mathrm{ND}=$ Not determined.

${ }^{4}$ Studies did not test for presence of the toxin genes but examined their expression (e.g., cytotoxicity).

${ }^{5}$ The $E$. coli $\mathrm{O} 157$ isolates were not typed for the $\mathrm{H}$ antigen.

${ }^{6}$ A nonmotile $E$. coli $\mathrm{O} 157$ isolate.

\section{PATHOGENICITY OF STEC FROM DAIRY CATTLE}

A few studies evaluated distribution of the virulence genes among STEC isolates from dairy cattle (Sandhu et al., 1996; Wilson et al., 1996; Byrne et al., 2003). For example, Wilson et al. (1996) reported the presence of the eae gene in 37\% of O157:H7 and non-O157:H7 STEC isolates. Sandhu et al. (1996) also showed that the eae gene was more frequently found ( $42 \%$ vs. $18 \%$ ) in STEC from calves than from cows. In the same study, $35 \%$ of E. coli $\mathrm{O} 157: \mathrm{H} 7$ strains were positive for the eae gene. Of the eae-positive isolates, 73\% produced only Stx1, suggesting a strong association between certain $\mathrm{O}$ serogroups (O5, O26, O69, O84, O103, O111, O145, and O157) and the eae gene. It was concluded, therefore, that Stx 1 production is more frequently associated with eae-positive than with eae-negative STEC strains (Sandhu et al., 1996). In another study, 57 E. coli O157:H7 isolates were tested for the presence of the $s t x_{1}, s t x_{2}$, eae, and ehxA genes (Byrne et al., 2003). Results showed $67 \%$ of the isolates to have the 4 genes, whereas the remaining isolates had various combinations of 3 genes at different rates (19\% had stx $x_{1}$,eae, and $e h x A ; 9 \%$ had $s t x_{2}, e a e$, and $e h x A$; and $5 \%$ had $s t x_{1}, s t x_{2}$, and eae). The presence of these virulence factors was evaluated for O157 (Table 5) and non-O157 STEC (Table 6) isolates from dairy cattle.

With regard to E. coli O157 (Table 5), some isolates had $s t x_{1}, s t x_{2}$, or both genes. The ability of this serotype, as well as other non-O157:H7 STEC strains, to cause human illnesses depends on the production of Stx1, Stx2, or both toxins (Karmali et al., 1985). All E. coli
O157:H7 isolates that were tested for the presence of the eae gene gave positive results (Table 5). Except for one isolate (Byrne et al., 2003), all of the tested ones also were positive for the $e h x A$ gene. Beutin et al. (1994) investigated human infections with $\mathrm{O} 157$ and nonO157 STEC (O26:H11, O111:H8, and $\left.\mathrm{O} 145: \mathrm{H}^{-}\right)$and reported that they had the eae and ehxA genes at high rates (92 and 88\%, respectively). Beutin et al. (1994) also reported that $E$. coli $\mathrm{O} 157: \mathrm{H} 7$ was responsible for the most severe illnesses (hemorrhagic colitis and HUS). The data in Table 5, therefore, suggest a high level of pathogenicity for several $E$. coli O157:H7 isolates of dairy cattle origin (Murinda et al., 2002; Byrne et al., 2003).

Table 6 shows that 44 STEC serotypes and members of $2 \mathrm{O}$ serogroups (O87 and O88) had only stx 1 , whereas 69 serotypes and members of $11 \mathrm{O}$ serogroups (O1, O8, O15, O21, O28, O104, O111, O158, O172, O174, and O175) had only $s t x_{2}$. Additionally, 41 serotypes and members of 6 O serogroups (O23, O38, O55, O73, O123, and 0125$)$ had both genes. Although isolates from 4 serotypes had only stx (OUT:H $^{-}$and OUT:HUT) or stx 2 (OUT:H8 and OUT:H21), the isolates from each of the remaining serotypes exhibited different toxin genotypes. For example, isolates from each of the $\mathrm{O} 22: \mathrm{H}^{-}$, O98: $\mathrm{H}^{-}, \mathrm{O} 113: \mathrm{H} 21, \mathrm{O} 145: \mathrm{H} 21, \mathrm{O} 153: \mathrm{H} 25, \mathrm{O} 153: \mathrm{H}^{-}$, and OUT:H7 serotypes had stx ${ }_{1}$ or $s t x_{2}$. Isolates from each of the O105:H18 and $\mathrm{O} 111: \mathrm{H}^{-}$serotypes had stx or both $s t x_{1}$ and $s t x_{2}$, whereas those from each of the O22:H16, O45:H8, O45:H9, O45:HUT, O82:H8, O116:H21, O153:H19, O153:HUT, O157:H', OUT:H16, 
Table 6. Virulence factors ${ }^{1}$ in non-O157 Shiga toxin-producing Escherchia coli from dairy cattle.

\begin{tabular}{|c|c|c|c|c|c|}
\hline \multicolumn{2}{|c|}{ Toxin genes } & \multicolumn{2}{|c|}{ Other genes } & \multirow[b]{2}{*}{ Serotype $^{2}$ or serogroup } & \multirow[b]{2}{*}{ Reference } \\
\hline$s t x_{1}$ & $s t x_{2}$ & eae & $e h x A$ & & \\
\hline \multirow[t]{17}{*}{+} & - & $\mathrm{ND}^{3}$ & ND & 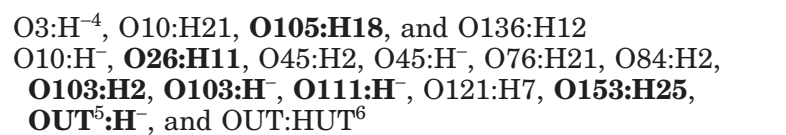 & $\begin{array}{l}\text { Montenegro et al., } 1990 \\
\text { Wells et al., } 1991^{7}\end{array}$ \\
\hline & & & & 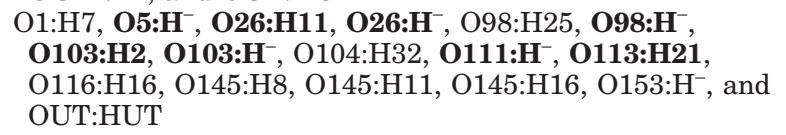 & Tada et al., $1992^{7}$ \\
\hline & & & & $\begin{array}{l}\mathrm{O} 22: \mathrm{H}^{-}, \mathrm{O} 70: \mathrm{H} 11, \mathrm{O} 74: \mathrm{H} 52, \text { O113:H21, O136:H1, } \\
\text { O145:H25, O156:H25, OUT:H7, and OUT:H }\end{array}$ & Miyao et al., $1998^{7}$ \\
\hline & & & & OUT:H- $\mathrm{H}^{-}$ & Cerqueira et al., 1999 \\
\hline & & & & 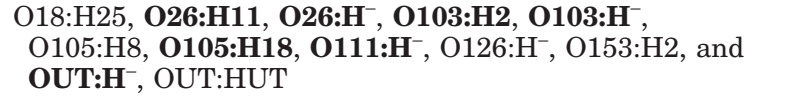 & Furuhata et al., $1999^{7}$ \\
\hline & & & & $\mathbf{O} 26: \mathbf{H}^{-}$ & Thran et al., 2001 \\
\hline & & & & $\mathrm{O} 5, \mathrm{O} 84, \mathrm{O} 87, \mathrm{O} 98$, and $\mathrm{O} 103$ & Orden et al., 2002 \\
\hline & & & + & $\mathrm{O} 26$ and $\mathrm{O} 103$ & Kobayashi et al., 2001 \\
\hline & & & & $\mathrm{O} 26$ & Zschöck et al., 2000 \\
\hline & & & - & $\mathrm{O} 26$ & Kobayashi et al., 2001 \\
\hline & & - & ND & O91:H41 and O146:H21 & Wilson et al., 1996 \\
\hline & & & & O26:H46, O26:H', and OUT:H $\mathbf{H}^{-}$ & Jung et al., 2000 \\
\hline & & & & OUT and $\mathrm{O} 136$ & Orden et al., 2002 \\
\hline & & & + & $\mathrm{O} 26, \mathrm{O} 84, \mathrm{O} 88$, and $\mathrm{O} 136$ & Kobayashi et al., 2001 \\
\hline & & & & OUT:HUT & Vernozy-Rozand et al., 2002 \\
\hline & & & - & O26 & Kobayashi et al., 2001 \\
\hline & & & & OUT:HUT & Vernozy-Rozand et al., 2002 \\
\hline \multirow[t]{19}{*}{-} & + & ND & ND & $\begin{array}{l}\text { O22:H8, O39:H40, O75:H8, O82:H8, O91:H10, } \\
\text { O113:H21, O116:H21, O126:H20, O126:H21, O139:H8, } \\
\text { OUT:H16, and OUT:H29 }\end{array}$ & Montenegro et al., 1990 \\
\hline & & & & $\begin{array}{l}\text { O22:H8, O116:H21, O145:H', O163:H19, O171:H2, } \\
\text { OX }^{8}: \mathrm{H} 21, \mathrm{OX} 3: \mathrm{H}^{-}, \mathrm{OR}^{9}: \mathrm{H} 2, \mathrm{OR}: \mathrm{H} 8, \text { and OR:H }\end{array}$ & Wells et al., 1991 \\
\hline & & & & 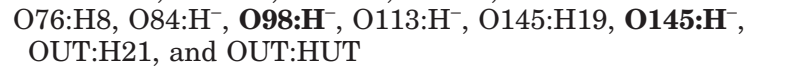 & Tada et al., 1992 \\
\hline & & & & 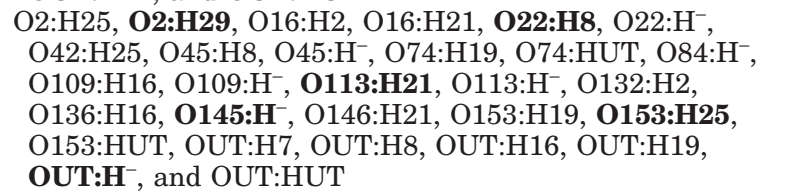 & Miyao et al., 1998 \\
\hline & & & & O22:H16, OUT:H18, and OUT:H28 & Cerqueira et al., 1999 \\
\hline & & & & 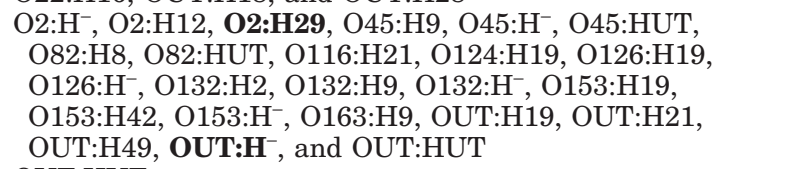 & Furuhata et al., 1999 \\
\hline & & & & OUT:HUT & Thran et al., 2001 \\
\hline & & + & & $\mathrm{O} 80: \mathrm{H}^{-}$ & Wilson et al., 1996 \\
\hline & & & & O172 & Orden et al., 2002 \\
\hline & & & + & O111 & Kobayashi et al., 2001 \\
\hline & & & - & O104 & Kobayashi et al., 2001 \\
\hline & & - & ND & $\mathrm{O} 7: \mathrm{H} 4$ and $\mathrm{O} 132: \mathrm{H}^{-}$ & Wilson et al., 1996 \\
\hline & & & & OUT:H21 and OUT:H ${ }^{-}$ & Jung et al., 2000 \\
\hline & & & & $\begin{array}{l}\mathrm{O} 2, \mathrm{O} 8, \mathrm{O} 21, \mathrm{O} 22, \mathrm{O} 74, \mathrm{O} 91, \mathrm{O} 113, \mathrm{O} 116, \mathrm{O} 174, \mathrm{O} 175, \\
\text { and OUT }\end{array}$ & Orden et al., 2002 \\
\hline & & & + & O28, O113, O116, O153, and $\mathrm{O} 163$ & Kobayashi et al., 2001 \\
\hline & & & & OUT:HUT & Vernozy-Rozand et al., 2002 \\
\hline & & & - & $\mathrm{O} 1, \mathrm{O} 2, \mathrm{O} 15, \mathrm{O} 113$, and $\mathrm{O} 158$ & Kobayashi et al., 2001 \\
\hline & & & & OUT:HUT & Vernozy-Rozand et al., 2002 \\
\hline & & & & OUT:H7 and OUT:H21 & Chiueh et al., 2002 \\
\hline \multirow[t]{3}{*}{+} & + & ND & ND & $\begin{array}{l}\text { O82:H8, O82:H40, O104:H21, O116:H21, O156:H21, and } \\
\text { OR:H18 }\end{array}$ & Montenegro et al., 1990 \\
\hline & & & & O15:H27 and O22:H8 & Wells et al., 1991 \\
\hline & & & & 0111: $\mathbf{H}^{-}$ & Tada et al., 1992 \\
\hline
\end{tabular}


Table 6 (Continued). Virulence factors ${ }^{1}$ in non-O157 Shiga toxin-producing Escherchia coli from dairy cattle.

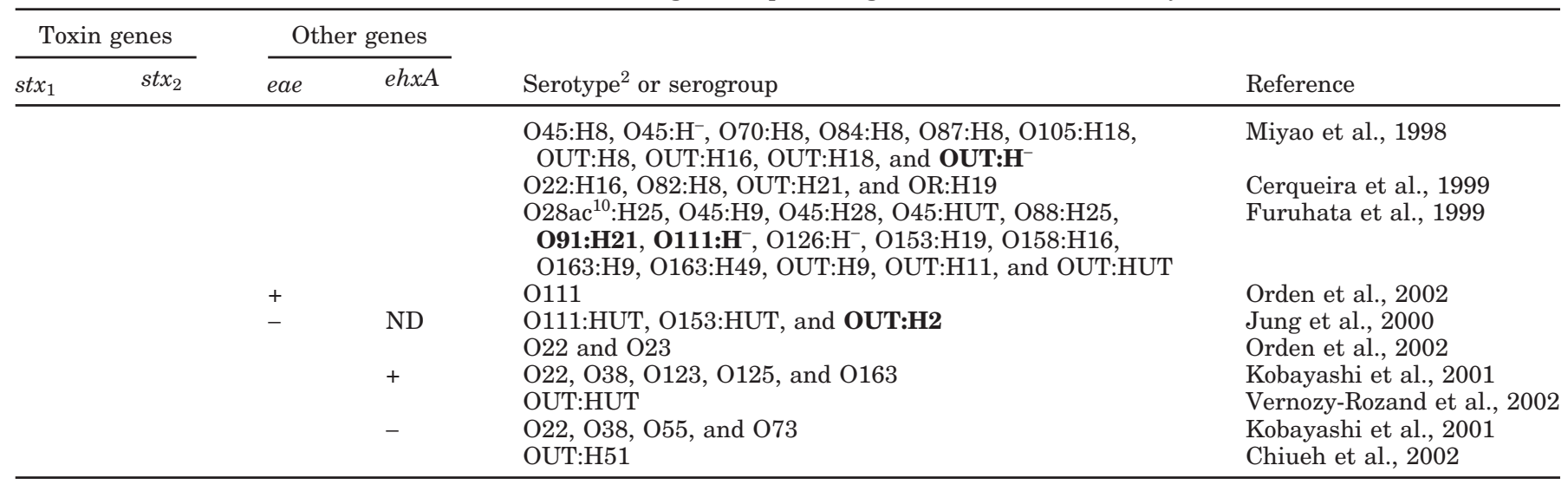

\footnotetext{
${ }^{1}$ The virulence factors include Shiga toxin $1\left(s t x_{1}\right)$, Shiga toxin $2\left(s t x_{2}\right), E$. coli attaching and effacing (eae), and enterohemolysin $(e h x A)$ genes.

${ }^{2}$ The serotypes in bold are known (WHO, 1998; Blanco et al., 2003) to cause hemolytic uremic syndrome.

${ }^{3} \mathrm{ND}=$ Not determined.

${ }^{4} \mathrm{H}^{-}=$A nonmotile $E$. coli isolate.

${ }^{5} \mathrm{OUT}=\mathrm{An}$ untypeable $\mathrm{O}$ antigen.

${ }^{6} \mathrm{HUT}=$ An untypeable $\mathrm{H}$ antigen.

${ }^{7}$ Studies did not test for presence of the toxin genes but examined their expression (e.g., cytotoxicity).

${ }^{8} \mathrm{OX} 3=$ Provisional designation for the $\mathrm{O} 174$ antigen.

${ }^{9} \mathrm{OR}=\mathrm{A}$ rough $\mathrm{O}$ antigen.

${ }^{10}$ Reflecting a certain antigenic relationship within the O28 serogroup in which "a" represents the common factor and "c" represents a specific factor (Lior, 1994).
}

OUT:H18, OUT:H21, OUT:H', and OUT:HUT serotypes had $s t x_{2}$ or both $s t x_{1}$ and $s t x_{2}$. Finally, isolates from each of the serotypes $\mathrm{O} 45: \mathrm{H}^{-}$and $\mathrm{O} 126: \mathrm{H}^{-}$had $s t x_{1}, s t x_{2}$, or both genes. Table 6 shows that 20 STEC serotypes (in bold) commonly isolated from dairy cattle are known to cause HUS (WHO, 1998; Blanco et al., 2003). Several other serotypes (O1:H7, O7:H4, $\mathrm{O} 15: \mathrm{H} 27, \mathrm{O} 22: \mathrm{H} 16, \mathrm{O} 22: \mathrm{H}^{-}, \mathrm{O} 45: \mathrm{H} 2, \mathrm{O} 45: \mathrm{H}^{-}, \mathrm{O} 70: \mathrm{H} 11$, $\mathrm{O} 80: \mathrm{H}^{-}$, O82:H8, O84:H2, O104:H21, O116:H21, $\mathrm{O} 126: \mathrm{H} 21, \mathrm{O} 126: \mathrm{H}^{-}, \mathrm{O} 132: \mathrm{H}^{-}, \mathrm{O} 145: \mathrm{H} 16, \mathrm{O} 146: \mathrm{H} 21$, O153:H2, O171:H2, OR:H-, OUT:H18, OUT:H19, and OUT:H21) in Table 6 are also known to cause diarrhea, bloody diarrhea, or hemorrhagic colitis (WHO, 1998).

Based on potential toxicity by having $s t x_{1}$ and/or $s t x_{2}$ genes, it is clear from Table 6 that it is not necessary for an isolate to have and express both genes to cause human illnesses. With regard to other virulence genes (eae and $e h x A$ ), unfortunately, the 20 STEC serotypes in Table 6 that are known to cause HUS were not evaluated for presence of the $e h x A$ gene. Of these serotypes, 5 $\left(\mathrm{O} 5: \mathrm{H}^{-}, \mathrm{O} 26: \mathrm{H}^{-}, \mathrm{O} 103: \mathrm{H} 2\right.$, OUT:H2, and $\left.\mathrm{OUT}: \mathrm{H}^{-}\right)$were evaluated for presence of the eae gene, and only $2\left(\mathrm{O} 5: \mathrm{H}^{-}\right.$ and O103:H2) tested positive. The ability of these eaepositive isolates to produce a functional intimin, however, was not reported. Investigating STEC pathogenicity (HUS cases) as affected by the presence of eae and $e h x A$ genes (Karch et al., 1997) revealed that most
STEC isolates were eae-positive. Several STEC strains involved in severe human illnesses (e.g., HUS), however, have lacked this gene or did not express a functional intimin (Keskimäki et al., 1997). This suggests that STEC strains lacking the eae gene can colonize the small intestine by expressing additional adherence factors. Studies of STEC in HUS patients showed that both eae and $e h x A$ genes were found in virtually all $E$. coli O157 strains (Beutin et al., 1994) but were more variably present among the non-O157 strains (Neill, 1997). The data in Tables 5 and 6 support this conclusion. Although the eae and $e h x A$ genes appear to be more common in the STEC strains associated with human illnesses, they are not absolutely required for pathogenicity, as strains lacking these genes have been shown to cause human illnesses (Neill, 1997).

\section{CONCLUSIONS}

The role of dairy cattle and their products in human infections with STEC was evaluated. These pathogens cause human illnesses ranging from mild diarrhea to the life-threatening HUS. Most STEC outbreaks were traced to the consumption of ground beef or dairy products. Contact with dairy farm environments by urban visitors also caused outbreaks of human illnesses. Longterm and short-term testing of dairy cattle feces world- 
wide showed high prevalence rates for $\mathrm{O} 157$ (ranging from 0.2 to $48.8 \%$ ) and non-O157 STEC (ranging from 0.4 to $74.0 \%$ ). Shiga toxin-producing $E$. coli were also isolated from raw milk, milk filters, and dairy products such as yogurt and soft cheeses. Dairy cattle, therefore, are considered reservoirs of STEC. The data summarized in this review showed 193 STEC serotypes to derive from dairy cattle origin. Of these serotypes, 24 have been isolated from HUS patients. Considering the wide distribution of STEC on dairy farms, the high prevalence rates reported, and the isolation of several serotypes of high virulence from dairy cattle or their products, long-term strategies to assure safety of foods from dairy cattle should be developed. These strategies should focus on establishing educational programs to bring awareness of the STEC problem to dairy farmers, processors, and consumers. Developing and implementing pre- and postharvest control methods to effectively decrease STEC carriage by dairy cattle and to eliminate contamination of their products during processing are essential steps toward sustaining a competitive dairy industry.

\section{ACKNOWLEDGMENTS}

The authors acknowledge the support of the USDA Integrated Research, Education, and Extension Competitive Grants Program (Grant No. 2001-05062).

\section{REFERENCES}

Abdul-Raouf, U. M., M. S. Ammar, and L. R. Beuchat. 1996. Isolation of Escherichia coli O157:H7 from some Egyptian foods. Int. J. Food Microbiol. 29:423-426.

Adams, M., and Y. Motarjemi. 1999. Basic Food Safety for Health Workers. World Health Organization, Geneva, Switzerland.

Allerberger, F., M. Wagner, P. Schweiger, H.-P. Rammer, A. Resch, M. P. Dierich, A. W. Friedrich, and H. Karch. 2001. Escherichia coli 0157 infections and unpasteurised milk. Eurosurveillance 6:147-151.

Anonymous. 1994. Two clusters of haemolytic uraemic syndrome in France. Commun. Dis. Rep. Wkly. 4:1.

Besser, T. E., and D. D. Hancock. 1994. Surveillance for Escherichia coli O157:H7: Seasonal variation and duration of infection in cattle. Pages FS13-FS16 in Proc. 8th Int. Congr. Anim. Hygiene. Int. Soc. Anim. Hygiene, St. Paul, MN.

Besser, T. E., D. D. Hancock, L. C. Pritchett, E. M. McRae, D. H. Rice, and P. I. Tarr. 1997. Duration of detection of fecal excretion of Escherichia coli O157:H7 in cattle. J. Infect. Dis. 175:726-729.

Beutin, L., S. Aleksic, S. Zimmermann, and K. Gleier. 1994. Virulence factors and phenotypical traits of verotoxigenic strains of Escherichia coli isolated from human patients in Germany. Med. Microbiol. Immunol. 183:13-21.

Bielaszewska, M., S. Herbert, L. Almut, P. Rita, R. Wolfgang, T. Helmut, C. Alois, J. Jan, B. Kveta, and K. Helge. 2000. Cattle can be a reservoir of sorbitol-fermentation Shiga toxin-producing Escherichia coli $\mathrm{O} 157: \mathrm{H}^{-}$strains and a source of human disease. J. Clin. Microbiol. 38:3470-3473.

Blanco, J., M. Blanco, J. E. Blanco, A. Mora, M. P. Alonso, E. A. González, and M. I. Bernárdez. 2001. Epidemiology of verocytotoxigenic Escherichia coli (VTEC) in ruminants. Pages 113-148 in Verocytotoxigenic Escherichia coli. G. Duffy, P. Garvey, and D. McDowell, ed. Food and Nutrition Press Inc., Trumbull, CT.
Blanco, J., M. Blanco, J. E. Blanco, A. Mora, E. A. González, M. I. Bernárdez, M. P. Alonso, A. Coira, A. Rodriguez, J. Rey, J. M. Alonso, and M. A. Usera. 2003. Verotoxin-producing Escherichia coli in Spain: Prevalence, serotypes, and virulence genes of O157:H7 and non-O157 VTEC in ruminants, raw beef products, and humans. Exp. Biol. Med. 228:345-351.

Bonardi, S., E. Maggi, A. Bottarelli, M. L. Pacciarini, A. Ansuini, G. Vellini, S. Morabito, and A. Caprioli. 1999. Isolation of Verocytotoxin-producing Escherichia coli O157:H7 from cattle at slaughter in Italy. Vet. Microbiol. 67:203-211.

Borczyk, A. A., M. A. Karmali, H. Lior, and L. M. C. Duncan. 1987. Bovine reservoir for verotoxin-producing Escherichia coli O157:H7. Lancet i:98.

Bürk, C., I. G. B. Braumiller, H. Becker, and E. Märtlbauer. 2002. Nuclease fluorescence assay for the detection of verotoxin genes in raw milk. Lett. Appl. Microbiol. 35:153-156.

Byrne, C. M., I. Erol, J. E. Call, C. W. Kaspar, D. R. Buege, C. J. Hiemke, P. J. Fedorka-Cray, A. K. Benson, F. M. Wallace, and J. B. Luchansky. 2003. Characterization of Escherichia coli O157:H7 from downer and healthy dairy cattle in the upper Midwest region of the United States. Appl. Environ. Microbiol. 69:4683-4688.

Cardinal, P. 1993. Isolation of Escherichia coli O157:H7 and detection of verotoxigenic $E$. coli in food and cattle feces in Quebec in 19901991. Pages 141-147 in Escherichia coli O157:H7 and Other Verotoxigenic E. coli in Foods. E. C. D. Todd and J. M. MacKenzie, ed. Food Directorate, Health Protection Branch, Health and Welfare Canada, and the Canadian Meat Council, Ottawa, Canada.

CDC. 1995. Outbreak of acute gastroenteritis attributable to Escherichia coli serotype O104:H21-Helena, Montana, 1994. Centers for Disease Control and Prevention. Morbid. Mortal. Wkly. Rep. 44:501-503

CDC. 2000. Outbreak of Escherichia coli O157:H7 infection associated with eating fresh cheese curds-Wisconsin, June 1998. Centers for Disease Control and Prevention. Morbid. Mortal. Wkly. Rep. 49:911-913.

CDSC. 1996. VTEC 0157 infection in West Yorkshire associated with the consumption of raw milk. Communicable Disease Surveillance Centre. Commun. Dis. Rep. Wkly. 6:181.

CDSC. 1998. Escherichia coli O157 infection and unpasteurized cream in England. Communicable Disease Surveillance Centre. Eurosurveillance Wkly. 2:981022.

CDSC. 1999a. VTEC O157 phage type 21/28 infection in North Cumbria. Update. Commun. Dis. Rep. CDR Wkly. 9:105.

CDSC. 1999b. Escherichia coli O157 associated with eating unpasteurised cheese - Update. Commun. Dis. Rep. CDR Wkly. 9:131-134.

Cerqueira, A. M. F., B. E. C. Guth, R. M. Joaquim, and J. R. C. Andrade. 1999. High occurrence of Shiga toxin-producing Escherichia coli (STEC) in healthy cattle in Rio de Janeiro State, Brazil. Vet. Microbiol. 70:111-121.

Chapman, P. A., C. A. Siddons, A. T. Cerdan Malo, and M. A. Harkin. 1997. A 1-year study of Escherichia coli O157 in cattle, sheep, pigs and poultry. Epidemiol. Infect. 119:245-250.

Chapman, P. A., D. J. Wright, P. Norman, J. Fox, and E. Crick. 1993. Cattle as a possible source of verocytotoxin-producing Escherichia coli 0157 infection in man. Epidemiol. Infect. 111:439-447.

Chiueh, L., F. Liu, and D. Y. Shih. 2002. Prevalence of Shiga toxinproducing Escherichia coli in feed and raw milk of domestic cattle and sheep. J. Food Drug Anal. 10:39-46.

Cieslak, P. R., T. J. Barrett, and P. M. Griffin. 1993. Escherichia coli O157:H7 infection from a manured garden. Lancet 342:367.

Clarke, R. C., J. B. Wilson, S. C. Read, S. Renwick, K. Rahn, R. P. Johnson, D. Alves, M. A. Karmali, H. Lior, S. A. McEwen, J. Spika, and C. L. Gyles. 1994. Verocytotoxin-producing Escherichia coli (VTEC) in the food chain: Preharvest and processing perspectives. Pages 17-24 in Recent Advances in Verocytotoxin-Producing Escherichia coli Infections. M. A. Karmali and A. G. Goglio, ed. Elsevier Science, Amsterdam, The Netherlands.

Coia, J. E., Y. Johnston, N. J. Steers, and M. F. Hanson. 2001. A survey of the prevalence of Escherichia coli O157 in raw meats, 
raw cow's milk and raw-milk cheeses in south-east Scotland. Int. J. Food Microbiol. 66:63-69.

Conedera, G., P. A. Chapman, S. Marangon, E. Tisato, P. Dalvit, and A. Zuin. 2001. A field survey of Escherichia coli O157 ecology on a cattle farm in Italy. Int. J. Food Microbiol. 66:85-93.

Correa, M. T., H. N. Erb, and J. M. Scarlett. 1993. Risk factors for downer cow syndrome. J. Dairy Sci. 76:3460-3463.

Crump, J. A., A. J. Langer, R. Gage, M. Baysinger, G. Withers, D. M. Toney, S. B. Hunter, M. Hoekstra, S. K. Wong, P. M. Griffin, and T. J. Van Gilder. 2002. An outbreak of Escherichia coli O157:H7 infections among visitors to a dairy farm. N. Engl. J. Med. 347:555-560.

Curnow, J. 1994. E. coli O157:H7 phage type 28 infections in Grampian. Commun. Dis. Environ. Health Scotland Wkly. Rep. 28:1.

Dean-Nystrom, E. A., B. T. Bosworth, W. C. Cray, Jr., and H. W. Moon. 1997. Pathogenecity of Escherichia coli O157:H7 in the intestines of neonatal calves. Infect. Immun. 65:1842-1848.

Deschênes, G., C. Casenave, F. Grimont, J. C. Desenclos, S. Benoit, M. Collin, S. Baron, P. Marian, P. A. Grimont, and H. Nivet. 1996. Cluster of cases of haemolytic uraemic syndrome due to unpasteurised cheese. Pediatr. Nephrol. 10:203-205.

Doyle, M. P. 1991. Escherichia coli O157:H7 and its significance in foods. Int. J. Food Microbiol. 12:289-302.

Ezawa, A., F. Gocho, K. Kawata, T. Takahashi, and N. Kikuchi. 2004. High prevalence of enterohemorrhagic Escherichia coli (EHEC) O157 from cattle in selected regions of Japan. J. Vet. Med. Sci. 66:585-587.

Faith, N. G., J. A. Shere, R. Brosch, K. W. Arnold, S. E. Ansay, M. S. Lee, J. B. Luchansky, and C. W. Kaspar. 1996. Prevalence and clonal nature of Escherichia coli $\mathrm{O} 157: \mathrm{H} 7$ on dairy farms in Wisconsin. Appl. Environ. Microbiol. 62:1519-1525.

Fitzgerald, A. C., T. S. Edrington, M. L. Looper, T. R. Callaway, K. J. Genovese, K. M. Bischoff, J. L. McReynolds, J. D. Thomas, R. C. Anderson, and D. J. Nisbet. 2003. Antimicrobial susceptibility and factors affecting the shedding of $E$. coli O157:H7 and Salmonella in dairy cattle. Lett. Appl. Microbiol. 37:392-398.

Franke, S., D. Harmsen, A. Caprioli, D. Pierard, L. H. Wieler, and H. Karch. 1995. Clonal relatedness of Shiga-like toxin-producing Escherichia coli $\mathrm{O} 101$ strains of human and porcine origin. J. Clin. Microbiol. 33:3174-3178.

Furuhata, K., S. Sakata, T. Okamoto, S. Yamamoto, M. Honda, A. Kai, T. Ito, M. Hara, K. Tabuchi, and M. Fukuyama. 1999. Prevalence and serotypes of verocytotoxin-producing Escherichia coli (VTEC) isolates from dairy cattle. Kansenshougaku Zasshi 73:445-450.

Gallien, P., H. Richter, H. Klie, M. Timm, H. Karch, K. W. Perlberg, H. Steinrück, S. Riemer, M. Djuren, and D. Protz. 1997. Detection of STEC and epidemiological investigations of a HUS patient. Berl. Münch. Tierärztl. Wochenschr. 110:342-346.

Garber, L. P., S. J. Wells, D. D. Hancock, M. P. Doyle, J. Tuttle, J. A. Shere, and T. Zhao. 1995. Public veterinary medicine: Food safety and handling-Risk factors for fecal shedding of Escherichia coli O157:H7 in dairy calves. JAVMA 207:46-49.

Garber, L., S. Wells, L. Schroeder-Tucker, and K. Ferris. 1999. Factors associated with fecal shedding of verotoxin-producing Escherichia coli $\mathrm{O} 157$ on dairy farms. J. Food Prot. 62:307-312.

Georgia Division of Public Health. 2002. Outbreaks of Escherichia coli O157:H7 infections among children associated with farm visitsPennsylvania and Washington, 2000. Available: http:// www.ph.dhr.state.ga.us/epi/news/apr01/042401.shtml. Accessed Dec. 18, 2003.

Griffin, P. M., and R. V. Tauxe. 1991. The epidemiology of infections caused by Escherichia coli O157:H7, other enterohemorrhagic $E$. coli, and the associated hemolytic uremic syndrome. Epidemiol. Rev. 13:60-98.

Hancock, D. D., T. E. Besser, M. L. Kinsel, P. I. Tarr, D. H. Rice, and M. G. Paros. 1994. The prevalence of Escherichia coli O157:H7 in dairy and beef cattle in Washington State. Epidemiol. Infect. 113:199-207.

Hancock, D. D., T. E. Besser, and D. H. Rice. 1998. Ecology of Escherichia coli $\mathrm{O} 157: \mathrm{H} 7$ in cattle and impact of management practices. Pages 85-91 in Escherichia coli O157:H7 and Other Shiga Toxin-
Producing E. coli Strains. J. B. Kaper and A. B. O’Brien, ed. ASM Press, Washington, DC.

Hancock, D. D., T. E. Besser, D. H. Rice, D. E. Herriott, and P. I. Tarr. 1997a. A longitudinal study of Escherichia coli O157 in fourteen cattle herds. Epidemiol. Infect. 118:193-195.

Hancock, D. D., D. H. Rice, D. E. Herriott, T. E. Besser, E. D. Ebel, and L. V. Carpenter. 1997b. Effects of farm manure handling practices on Escherichia coli $\mathrm{O} 157: \mathrm{H} 7$ prevalence in cattle. J. Food Prot. 60:363-366.

Hancock, D. D., D. H. Rice, L. A. Thomas, D. A. Dargatz, and T. E. Besser. 1997c. Epidemiology of Escherichia coli O157 in feedlot cattle. J. Food Prot. 60:462-465.

Herriott, D. E., D. D. Hancock, W. E. Keene, and D. H. Rice. 1994 Raw milk associated E. coli O157:H7 outbreaks in Oregon. Pages FS17-FS21 in Proc. 8th Int. Congr. Anim. Hygiene. Int. Soc. Anim. Hygiene, St. Paul, MN.

Heuvelink, A. E., F. L. A. M. Van den Biggelaar, J. T. M. ZwartkruisNahuis, R. G. Herbes, R. Huyben, N. Nagelkerke, W. J. G. Melchers, L. A. H. Monnens, and E. de Boer. 1998. Occurrence of verotoxin-producing Escherichia coli $\mathrm{O} 157$ on Dutch dairy farms. J. Clin. Microibiol. 36:3480-3487.

International Association of Milk, Food, and Environmental Sanitarians. 2000. Outbreaks of VTEC O157 infection linked to consumption of unpasteurized milk. Assoc. Milk Food Environ. San. 20:627.

Jackson, S. G., R. B. Goodbrand, R. P. Johnson, V. G. Odorico, D. Alves, K. Rahn, J. B. Wilson, M. K. Welch, and R. Khakhria. 1998. Escherichia coli O157:H7 diarrhoea associated with well water and infected cattle on an Ontario farm. Epidemiol. Infect. 120:17-20.

Jung, B., S. Jung, H. Park, G. Cho, and B. Kim. 2000. Characteristics of verotoxin non-producing Escherichia coli $\mathrm{O} 157$ and verotoxinproducing $E$. coli isolated from healthy cattle. Korean J. Vet. Res. 40:525-531.

Karch, H., H. I. Huppertz, J. Bockemuhl, H. Schmidt, A. Schwarzkopf, and R. Lissner. 1997. Shiga toxin-producing Escherichia coli infections in Germany. J. Food Prot. 60:1454-1457.

Karmali, M. A., M. Petric, C. Lim, P. C. Fleming, G. S. Arbus, and H. Lior. 1985. The association between idiopathic hemolytic-uremic syndrome and infection by verotoxin-producing Escherichia coli. J. Infect. Dis. 151:775-782.

Keene, W. E., K. Hedberg, D. E. Herriott, D. D. Hancock, R. W. McKay, T. J. Barrett, and D. W. Fleming. 1997. A prolonged outbreak of Escherichia coli O157:H7 infections caused by commercially distributed raw milk. J. Infect. Dis. 176:815-818.

Keene, W. E., J. M. McAnulty, F. C. Hoesly, L. P. Williams, K. Hedberg, G. L. Oxman, T. J. Barrett, M. A. Pfaller, and D. W. Fleming. 1994. A swimming-associated outbreak of hemorrhagic colitis caused by Escherichia coli O157:H7 and Shigella sonnei. N. Engl. J. Med. 331:579-584.

Keskimäki, M., R. Ikäheimo, P. Kärkkäinen, F. Scheutz, Y. Ratiner, R. Puohiniemi, and A. Siitonen. 1997. Shiga toxin-producing Escherichia coli serotype OX3:H21 as a cause of hemolytic-uremic syndrome. Clin. Infect. Dis. 24:1278-1279.

Klie, H., M. Timm, H. Richter, P. Gallien, K. W. Perlberg, and H. Steinruck. 1997. Detection and occurrence of verotoxin-forming and/or Shigatoxin producing Escherichia coli (VTEC and/or STEC) in milk. Berl. Munch. Tierärztl. Wochenschr. 110:337-341.

Kobayashi, H., J. Shimada, M. Nakazawa, T. Morozumi, T. Pohjanvirta, S. Pelkonen, and K. Yamamoto. 2001. Prevalence and characteristics of Shiga toxin-producing Escherichia coli from healthy cattle in Japan. Appl. Environ. Microbiol. 67:484-489.

Lahti, E., M. Eklund, P. Ruutu, A. Siitonrn, L. Rantala, P. Nuorti, and T. Honkanen-Buzalski. 2002. Use of phenotyping and genotyping to verify transmission of Escherichia coli O157:H7 from dairy farms. Eur. J. Clin. Microbiol. Infect. Dis. 21:189-195.

Lior, H. 1994. Classification of Escherichia coli. Pages 31-72 in Escherichia coli in Domestic Animals and Humans. C. L. Gyles, ed. CAB Int., Wallingford, UK.

Martin, M. L., L. D. Shipman, J. G. Wells, M. E. Potter, K. Hedberg, I. K. Wachsmuth, R. V. Tauxe, J. P. Davis, J. Arnoldi, and J. Tilleli. 1986. Isolation of Escherichia coli O157 from dairy cattle 
associated with two cases of haemolytic uremic syndrome. Lancet ii:1043.

McKee, R., R. H. Madden, and A. Gilmour. 2003. Occurrence of verocytotoxin-producing Escherichia coli in dairy and meat processing environments. J. Food Prot. 66:1576-1580.

Mechie, S. C., P. A. Chapman, and C. A. Siddons. 1997. A fifteenmonth study of Escherichia coli O157:H7 in a dairy herds. Epidemiol. Infect. 118:17-25.

Miyao, Y., T. Kataoka, T. Nomoto, A. Kai, T. Itoh, and K. Itoh. 1998. Prevalence of verotoxin-producing Escherichia coli harbored in the intestine of cattle in Japan. Vet. Microbiol. 61:137-143.

Montenegro, M. A., M. Bülte, T. Trumpf, S. Aleksiá, G. Reuter, E. Bulling, and R. Helmuth. 1990. Detection and characterization of fecal verotoxin-producing Escherichia coli from healthy cattle. J. Clin. Microbiol. 28:1417-1421.

Moreira, C. N., M. A. Pereira, C. S. Brod, D. P. Rodrigues, J. B. Carvalhal, and J. A. G. Aleixo. 2003. Shiga toxin-producing Escherichia coli (STEC) isolated from healthy dairy cattle in southern Brazil. Vet. Microbiol. 93:179-183.

Morgan, D., C. P. Newman, D. N. Hutchinson, A. M. Walker, B. Rowe, and F. Majid. 1993. Verotoxin producing Escherichia coli O157 infections associated with the consumption of yoghurt. Epidemiol. Infect. 111:181-187.

Murinda, S. E., L. T. Nguyen, S. J. Ivey, B. E. Gillespie, R. A. Almeida, F. A. Draughon, and S. P. Oliver. 2002. Prevalence and molecular characterization of Escherichia coli $\mathrm{O} 157: \mathrm{H} 7$ in bulk tank milk and fecal samples from cull cows: A 12-month survey of dairy farms in East Tennessee. J. Food Prot. 65:752-759.

National Cattlemen's Beef Association. 2001. Cattle and Beef Industry Statistics. National Cattlemen's Beef Association, Centennial, CO.

Neill, M. A. 1997. Overview of Verotoxigenic Escherichia coli. J. Food Prot. 60:1444-1446.

Nielsen, E. M., C. Teqtmeier, H. J. Anderson, C. Grønbæk, and J. S. Andersen. 2002. Influence of age, sex and herd characteristics on the occurrence of verocytotoxin-producing Escherichia coli 0157 in Danish dairy farms. Vet. Microbiol. 88:245-257.

O'Brien, A. D., and R. K. Holmes. 1987. Shiga and Shiga-like toxins. Microbiol. Rev. 51:206-220.

Orden, J. A., D. Cid, J. A. Ruiz-Santa-Quireria, S. García, S. Martínez, and R. de la Fuente. 2002. Verotoxin-producing Escherichia coli (VTEC), enteropathogenic $E$. coli (EPEC) and necrotoxigenic $E$. coli (NTEC) isolated from healthy cattle in Spain. J. Appl. Microbiol. 93:29-35.

Ostroff, S. M., P. M. Griffin, R. V. Tauxe, L. D. Shipman, K. D. Greene, J. G. Wells, J. H. Lewis, P. A. Blake, and J. M. Kobayashi. 1990. A statewide outbreak of Escherichia coli O157:H7 infections in Washington State. Am. J. Epidemiol. 132:239-247.

Padhye, N. V., and M. P. Doyle. 1991. Rapid procedure for detecting enterohemorrhagic Escherichia coli O157:H7 in food. Appl. Environ. Microbiol. 57:2693-2698.

Paton, J. C., and A. W. Paton. 2000. Shiga toxigenic Escherichia coli infections. Sci. Med. May/June:28-37.

Pradel, N., K. Boukhors, Y. Bertin, C. Forestier, C. Martin, and V. Livrelli. 2001. Heterogeneity of Shiga toxin-producing Escherichia coli strains isolated from hemolytic-uremic syndrome patients, cattle, and food samples in central France. Appl. Environ. Microbiol. 67:2460-2468.

Pradel, N., V. Livrell, C. de Champs, J. Palcoux, A. Reynaud, F. Scheutz, J. Sirot, B. Joly, and C. Forestier. 2000. Prevalence and characterization of Shiga toxin-producing Escherichia coli isolated from cattle, food, and children during a one-year prospective study in France. J. Clin. Microbiol. 38:1023-1031.

Rahn, K., S. A. Renwick, R. P. Johnson, J. B. Wilson, R. C. Clarke, D. Alves, S. McEwen, H. Lior, and J. Spika. 1997. Persistence of Escherichia coli 0157:H7 in dairy cattle and the dairy farm environment. Epidemiol. Infect. 119:251-259.

Rahn, K., S. A. Renwick, R. P. Johnson, J. B. Wilson, R. C. Clarke, D. Alves, S. A. McEwen, H. Lior, and J. Spika. 1998. Follow-up study of verocytotoxigenic Escherichia coli infection in dairy farm family. J. Infect. Dis. 177:1138-1139.
Reid, T. M. S. 2001. A case study of cheese associated E. coli 0157 outbreaks in Scotland. Pages 201-212 in Verocytotoxigenic Escherichia coli. G. Duffy, P. Garvey, and D. McDowell, ed. Food and Nutrition Press Inc., Trumbull, CT.

Reida, P., M. Wolff, H. W. Pohls, W. Kuhlmann, A. Lehmacher, S. Aleksic, H. Karch, and J. Bockemuhl. 1994. An outbreak due to enterohemorrhagic Escherichia coli $\mathrm{O} 157: \mathrm{H} 7$ in a children day care center characterized by person-to-person transmission and environmental contamination. Zentralbl. Bakteriol. 281:534-543.

Reitsma, C. J., and D. R. Henning. 1996. Survival of enterohemorrhagic Escherichia coli O157:H7 during the manufacture and curing of Cheddar cheese. J. Food Prot. 59:460-464.

Rice, D. H., E. D. Ebel, D. D. Hancock, T. E. Besser, D. E. Herriott, and L. V. Carpenter. 1997. Escherichia coli O157 in cull dairy cows on farm and at slaughter. J. Food Prot. 60:1386-1387.

Riemann, H. P., and D. O. Cliver. 1998. Escherichia coli O157:H7. Pages 41-48 in The Veterinary Clinics of North America-Food Animal Practice: Microbial Food Borne Pathogens. L. Tollefson, ed. W. B. Saunders Co., Philadelphia, PA.

Rugbjerg, H., E. M. Nielsen, and J. S. Andersen. 2003. Risk factors associated with faecal shedding of verocytotoxin-producing Escherichia coli O157 in eight known-infected Danish dairy herds. Prev. Vet. Med. 58:101-113.

Sandhu, K. S., R. C. Clarke, K. McFadden, A. Brouwer, M. Louie, J. Wilson, H. Lior, and C. L. Gyles. 1996. Prevalence of the eaeA gene in verotoxigenic Escherichia coli strains from dairy cattle in Southwest Ontario. Epidemiol. Infect. 116:1-7.

Segelken, R. 1996. E. coli screen aims to keep bacteria out of hamburger. Available: http://www.news.cornell.edu/releases/May96/ beefQA.hrs.html. Accessed Jan. 19, 2004.

Shinagawa, K., M. Kanehira, K. Omoe, I. Matsuda, D. Hu, D. A. Widiasih, and S. Sugii. 2000. Frequency of Shiga toxin-producing Escherichia coli in cattle at a breeding farm and at a slaughterhouse in Japan. Vet. Microbiol. 76:305-309.

Siegler, R. L., M. K. Milligan, T. H. Burningham, R. D. Christofferson, S. Y. Changand, and L. B. Jorde. 1991. Long term renal outcome and prognostic indicators in the hemolytic-uremic syndrome. J. Pediatr. 118:195-200.

Steele, M. L., W. B. McNab, C. Poppe, M. W. Griffiths, S. Chen, S. A. Degrandis, L. C. Fruhner, C. A. Larkin, J. A. Lynch, and J. A. Odumeru. 1997. Survey of Ontario bulk raw milk for foodborne pathogens. J. Food Prot. 60:1341-1346.

Tada, H., S. Itami, Y. Yamamoto, K. Kobayashi, M. Taguchi, and M. Nakazawa. 1992. Detection of verotoxin-producing Escherichia coli using polymerase chain reaction from dairy cattle. Kasnenshougaku Zasshi 66:1383-1389.

Thran, B. H., H. S. Hussein, M. R. Hall, and S. F. Khaiboullina. 2001. Occurrence of verotoxin-producing Escherichia coli in dairy heifers grazing an irrigated pasture. Toxicology 159:159-169.

Todd, E., R. Szabo, and J. MacKenzie. 1993. Cultural and enzymelinked antibody methods to detect Escherichia coli O157:H7. Pages 39-52 in Escherichia coli O157:H7 and Other Verotoxigenic E. coli in Foods. E. C. D. Todd and J. M. MacKenzie, ed. Food Directorate, Health Protection Branch, Health and Welfare Canada, and the Canadian Meat Council, Ottawa, Canada.

Troutt, H. F., and B. I. Osburn. 1997. Meat from dairy cows: Possible microbiological hazards and risks. Rev. Sci. Technol. Off. Int. Epizoot. 16:405-414.

USDA. 1992. Agricultural Statistics 1992. Agricultural Statistics Board, USDA, Washington, DC.

USDA-APHIS-VS. 1994. Escherichia coli O157:H7 in US Dairy Calves. January Report, National Animal Health Monitoring System. USDA Animal and Plant Health Inspection Service, Veterinary Service, Centers for Epidemiology and Animal Health, Fort Collins, CO.

USDA-APHIS-VS. 1996a. Economic opportunities for dairy cow culling management options. Info Sheet. USDA Animal and Plant Health Inspection Service, Veterinary Service, Centers for Epidemiology and Animal Health, Fort Collins, CO.

USDA-APHIS-VS. 1996b. New York cull cow study on Escherichia coli O157:H7. APHIS Report of FY 1995. Accomplishments in Animal Production Food Safety. USDA Animal and Plant Health 
Inspection Service, Veterinary Service, Centers for Epidemiology and Animal Health, Fort Collins, CO.

USDA-APHIS-VS. 1997. An update: Escherichia coli O157:H7 in humans and cattle. USDA Animal and Plant Health Inspection Service, Veterinary Service, Centers for Epidemiology and Animal Health, Fort Collins, CO.

Van Donkersgoed, J., T. Graham, and V. Gannon. 1999. The prevalence of verotoxins, Escherichia coli O157:H7, and Salmonella in the feces and rumen of cattle at processing. Can. Vet. J. 40:332-338.

Vernozy-Rozand, C., M. P. Montet, F. Lequerrec, E. Serillon, B. Tilly, C. Bavai, S. Ary-Gueniot, J. Bouvet, C. Mazuy-Cruchaudet, and Y. Richard. 2002. Prevalence of verotoxin-producing Escherichia coli (VTEC) in slurry, farmyard manure and sewage sludge in France. J. Appl. Microbiol. 93:473-478.

Wall, P. G., R. J. McDonnell, G. K. Adak, T. Cheasty, H. S. Smith, and B. Rowe. 1996. General outbreaks of verocytotoxin producing Escherichia coli O157 in England and Wales from 1992 to 1994. Commun. Dis. Rep. CDR Rev. 6:R26-R33.

Wells, J. G., L. D. Shipman, K. D. Greene, E. G. Sowers, J. H. Green, D. N. Cameron, F. P. Downes, M. L. Martin, P. M. Griffin, S. M. Ostroff, M. E. Potter, R. V. Tauxe, and K. I. Wachsmuth. 1991. Isolation of Escherichia coli serotype O157:H7 and other Shigalike-toxin-producing $E$. coli from dairy cattle. J. Clin. Microbiol. 29:985-989.
WHO. 1998. Zoonotic non-O157 Shiga toxin-producing Escherichia coli (STEC). Report of a WHO Scientific Working Group Meeting. World Health Organization, Geneva, Switzerland.

Wilson, J. B., R. C. Clarke, S. A. Renwick, K. Rahn, R. P. Johnson, M. A. Karmali, H. Lior, D. Alves, C. L. Gyles, K. S. Sandhu, S. A. McEwen, and J. S. Spika. 1996. Vero cytotoxigenic Escherichia coli infection in dairy farm families. J. Infect. Dis. 174:1021-1027.

Wilson, J. B., R. P. Johnson, R. C. Clarke, K. Rahn, S. A. Renwick, D. Alves, M. A. Karmali, P. Michel, E. Orrbine, and J. S. Spika. 1997. Canadian perspectives on verotoxin-producing Escherichia coli infection. J. Food Prot. 60:1451-1453.

Wilson, J. B., S. A. McEwen, R. C. Clarke, K. E. Leslie, R. A. Wilson, D. Waltner-Toews, and C. L. Gyles. 1992. Distribution and characteristics of verotoxigenic Escherichia coli isolated from Ontario dairy cattle. Epidemiol. Infect. 108:423-439.

Yatsuyanagi, J., S. Saito, and I. Ito. 2002. A case of hemolytic-uremic syndrome associated with Shiga toxin 2-producing Escherichia coli $\mathrm{O} 121$ infection caused by drinking water contaminated with bovine feces. Jpn. J. Infect. Dis. 55:174-176.

Zhao, T., M. P. Doyle, J. Shere, and L. Garber. 1995. Prevalence of Escherichia coli O157:H7 in a survey of dairy herds. Appl. Environ. Microbiol. 61:1290-1293.

Zschöck, M., H. P. Hamann, B. Kloppert, and W. Wolter. 2000. Shigatoxin-producing Escherichia coli in faeces of healthy dairy cows, sheep and goats: Prevalence and virulence properties. Lett. Appl. Microbiol. 31:203-208. 